\title{
Comparison of Radionuclide Levels in Soil, Sagebrush, Plant Litter, Cryptogams, and Small Mammals
}

D. S. Landeen

Westinghouse Hanford Company

- Date Published

September 1994

Prepared for the U.S. Department of Energy Office of Environmental Restoration and Waste Management

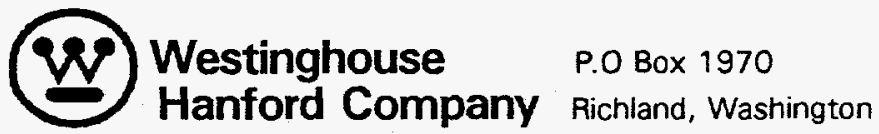

Hanford Operations and Engineering Contractor for the

U.S. Department of Energy under Contract DE-AC06-87RL10930 


\section{DISCLAIMER}

This report was prepared as an account of work sponsored by an agency of the United States Government. Neither the United States Government nor any agency thereof, nor any of their employees, make any warranty, express or implied, or assumes any legal liability or responsibility for the accuracy, completeness, or usefulness of any information, apparatus, product, or process disclosed, or represents that its use would not infringe privately owned rights. Reference herein to any specific commercial product, process, or service by trade name, trademark, manufacturer, or otherwise does not necessarily constitute or imply its endorsement, recommendation, or favoring by the United States Government or any agency thereof. The views and opinions of authors expressed herein do not necessarily state or reflect those of the United States Government or any agency thereof. 


\section{RELEASE AUTHORIZATION}

Document Number: $\quad$ WHC-EP-0771

Comparison of Radionuclide Levels in Soil, Sagebrush, Plant Litter, Cryptogams and Small Mammals

Release Date: $\quad 5 / 28 / 94$

This document was reviewed following the procedures described in WHC-CM-3-4 and is:

APPROVED FOR PUBLIC RELEASE

* * * * * * * * * * * * *

WHC Information Release Administration Specialist:

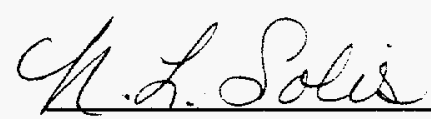

N.L. SOLIS

(Signature)

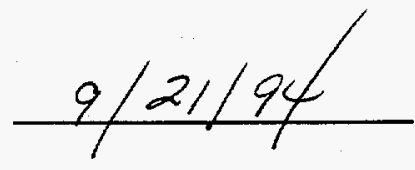

(Date) 


\section{COMPARISON OF RADIONUCLIDE LEVELS IN SOILS, SAGEBRUSH, PLANT LITTER, CRYPTOGAMS, AND SMALL MAMMALS}

\section{EXECUTIVE SUMMARY}

Soi1, sagebrush, plant litter, cryptogam, and small mammal samples were collected and analyzed for cesium-137, strontium-90, plutonium-238, plutonium 239/240, technetium-99, and iodine-129 from 1981 to 1986 at the U.S.

Department of Energy Hanford Site in southeastern Washington State as part of site characterization and environmental monitoring activities. Samples were collected on the 200 Areas Plateau, downwind from ongoing waste management activities.

Plant litter, cryptogams, and small mammals are media that are not routinely utilized in monitoring or characterization efforts for determination of radionuclide concentrations. Studies at Hanford, other U.S. Department of Energy sites, and in eastern Europe have indicated that plant litter and cryptogams may serve as effective "natural" monitors of air quality. Plant litter in this study consists of fallen leaves from sagebrush and "cryptogams" describes that portion of the soil crust composed of mosses, 1 ichens, algae, and fungi.

Comparisons of cesium-137 and strontium-90 concentrations in the soil, sagebrush, litter, and cryptogams revealed significantly higher $(p<0.05)$ levels in plant litter and cryptogams. Technetium-99 values were the highest in sagebrush and litter. Plutonium-238 and 239/40 and iodine-129 concentrations never exceeded $0.8 \mathrm{pCi} / \mathrm{gm}$ in a 11 media. No evidence of any 


\section{WHC-EP-0771}

significant amounts of any radionuclides being incorporated into the small mammal community was discovered.

The data indicate that $\mathrm{plant}$ litter and cryptogams may be better indicators of environmental quality than soil or vegetation samples. Augmenting a monitoring program with samples of litter and cryptogams may provide a more accurate representation of radionuclide environmental uptake and/or contamination levels in surrounding ecosystems. The results of this study may be applied directly to other radioecological monitoring conducted at other nuclear sites and to the monitoring of other pollutants. 
WHC-EP-0771

CONTENTS

INTRODUCTION . . . . . . . . . . . . . . . . . . . . . . . . . . . 1

MATERIALS AND METHODS . . . . . . . . . . . . . . . . . . . . 3

RESULTS . . . . . . . . . . . . . . . . . . . . . . . . 5

CRYPTOGAM ECOLOGY . . . . . . . . . . . . . . . . . 5

RADIONUCLIDE RESULTS . . . . . . . . . . . . . . . . . . . . 5

DISCUSSION . . . . . . . . . . . . . . . . . . . . . . 8

SOIL . . . . . . . . . . . . . . . . . . 8

SAGEBRUSH ........................ . 8

LITTER . . • . . . . . . . . . . . . . . . . . 9

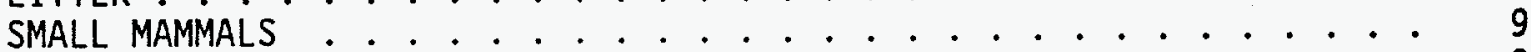

CRYPTOGAMS (MOSSES) . . . . . . . . . . . . . . . . . . . 9

SUMMARY . . . . . . . . . . . . . . . . . . . . . . 11

REFERENCES ............................... . . . . 11

APPENDIX A . . . . . . . . . . . . . . . . . . . . . . A-1

\section{LIST OF TABLES}

1 Average Radionuclide Concentrations in Various Environmental Media . . 5

2 Mean Concentration Ratios for ${ }^{137} \mathrm{Cs}$ and ${ }^{90} \mathrm{Sr}$

(pCi/gm sample media/pCi/gm soil) ................. 6

\section{LIST OF FIGURES}

1 Hanford Site in Southeastern Washington State . . . . . . . . . . 2

2 Locations and Sample Station Numbers of

Radioecology Sampling Stations... . . . . . . . . . . . . . 4

3 Locations and Sample Station Numbers of Radioecology Sampling Stations

in Relation to the Wye Barricade. . . . . . . . . . . . . 4

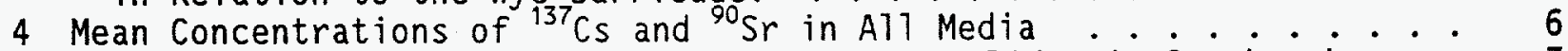

5 Mean Concentration Ratios of Selected Radionuclides in Sagebrush . . . 7 
WHC-EP-0771

TERMS

DOE

U.S. Department of Energy

ORNL

Oak Ridge National Laboratory

Plutonium-Uranium Extraction (P1ant) 


\section{INTRODUCTION}

The routine monitoring of soil, water, and vegetation at many nuclear facilities throughout the country for radionuclides and heavy metals is well documented (Hunter 1992, Cummins et a7. 1989, Cirrincione and Costain 1990). At the U.S. Department of Energy (DOE) Hanford Site in southeastern Washington State (Figure 1), soil and vegetation samples are collected routinely to monitor radionuclide levels (Schmidt et a1. 1993, Woodruff et al. 1993).

In support of special projects for the Plutonium-Uranium Extraction (PUREX) Plant and the Grout Treatment Facility from 1981 to 1986, soil, sagebrush leaves and twigs (Artemisia tridentata), ${ }^{\mathrm{p} l a n t}$ litter, cryptogams,
and small mammals were collected and analyzed for ${ }^{137} \mathrm{Cs},{ }^{90} \mathrm{Sr},{ }^{238} \mathrm{P}$, $239 / 240 \mathrm{P}$, ${ }^{99} \mathrm{Tc}$, and ${ }^{129} \mathrm{I}$. Plant litter, cryptogams, and small mammals are not routinely analyzed for radionuclide concentrations.

Plant litter was primarily composed of fallen leaves from sagebrush and was collected and analyzed to determine differences in the accumulations of radionuclides between this material and the live plant. Plant litter was collected at the Hanford Site in an earlier study (Vaughan 1978) and was analyzed for mineral content. That study indicated that leaf litter could be a useful ecological indicator for monitoring the effects of salt drift from cooling towers and gaseous and particulate airborne effluents from coal-fired steam-electric plants.

Small mammals also serve as indicators of environmental quality. Several studies at the Hanford Site (Vaughan 1978, Schmidt et a1. 1992, and Landeen and Mitchel1 1982) and other nuclear sites (Garten 1981, Hakonson and Gladney 1981, Arthur and Markham 1982) have shown that small mammals can take up radionuclides and other pollutants (Scanlon 1979 and Talmage and Walton 1991).

The term cryptogam describes a living soil crust composed of mosses, lichens, algae, and fungi. Data from other studies (Garner and Jenkins 1991, Sawidis and Heinrich 1992, Thomas et al. 1992, Mihok et al. 1989, and Richardson 1992) have indicated that lichens are effective natural monitors of air pollution, acting as sinks for the accumulation of airborne materials. Cesium-137 concentrations were four times higher in lichens and mushrooms collected on granite outcrops in Georgia than in the surrounding pine-hardwood forest (Garner and Jenkins 1991). Lichens and mosses have been analyzed for radionuclides in the Arctic (Thomas et a7. 1992) and Alaska (Rickard et al. 1965) because many wildlife species depend on lichens as a primary food source. Hoffman et al. (1993) suggested that lichens are more suitable biological detectors for monitoring fallout radionuclides than soil samples.

Mosses also serve as efficient filters for trapping airborne particles (Mattsson and Liden 1975, Svoboda et a1. 1986). They seem to be more efficient than lichens at taking up and accumulating heavy metals and are probably the plants used most frequently to monitor for metal pollutants in terrestrial habitats (Burton 1986). Studies in Canada (Glooschenko and Capobianco 1978 and Barclay-Estrup and Rinne 1978) and the northeastern United States (Groet 1976) have utilized sphagnum, feather, and other types of mosses to monitor concentrations of heavy metals. 
Figure 1. Hanford Site in Southeastern Washington State.

The Hanford Site

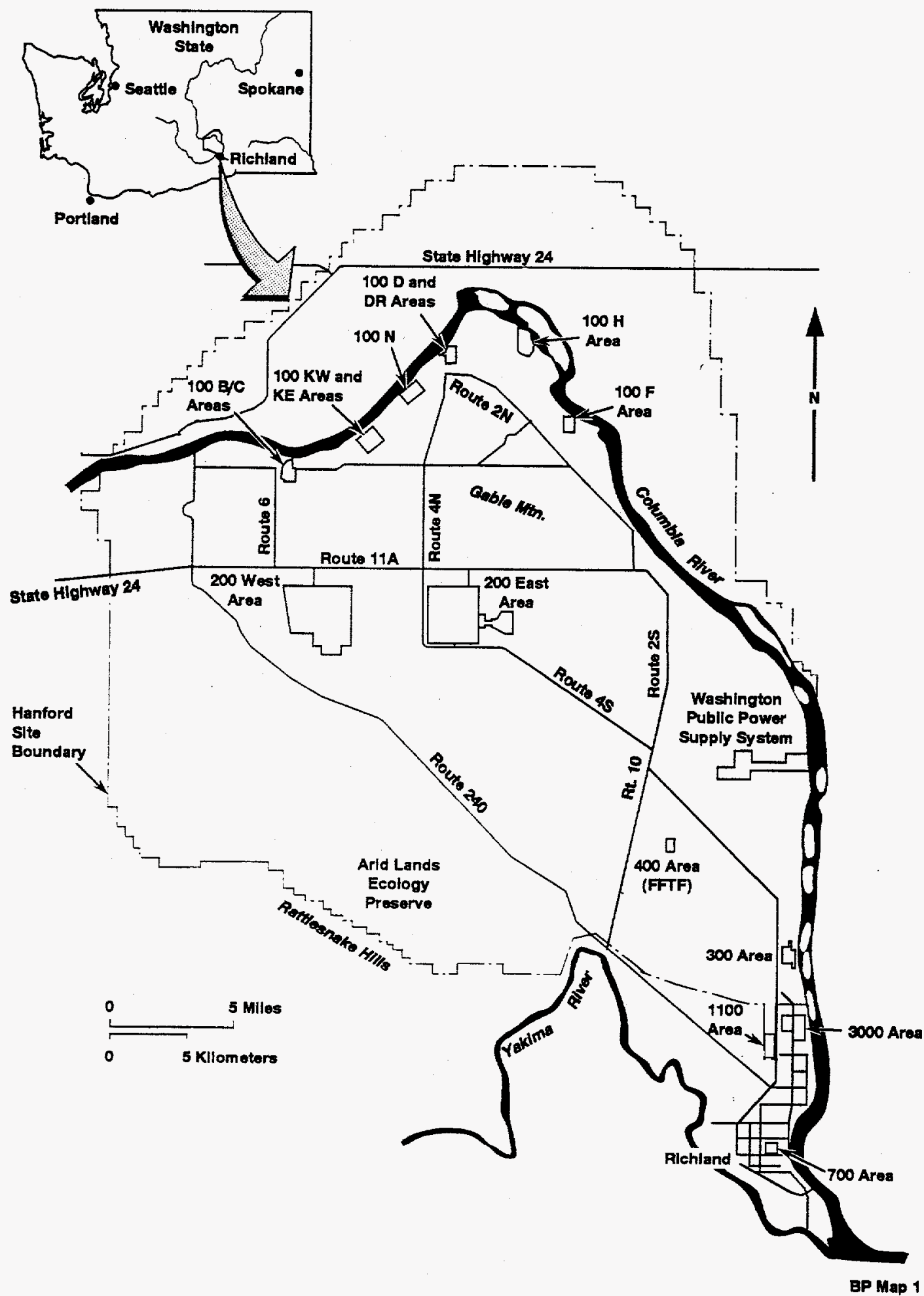


In Sweden, Folkeson (1979) found that five mosses accumulated greater concentrations of heavy metals than the four lichen species used for comparison. Mosses were found to accumulate mercury by an order of magnitude greater than grasses and other vegetation around Oak Ridge, Tennessee (Huckabee 1973). Mosses on trees near a pulp mill at Lewiston, Idaho were sampled for sulfur gases (Hoffman, 1974) to assess ecological impacts. Wallin (1976) utilized mosses in Sweden to monitor the deposition of airborne mercury. Pilegaard (1979) showed a strong linear association between concentrations of metals in mosses near a Danish steelworks and Boileau et al. (1982) demonstrated that the mineral content of mosses accurately reflects urban emission patterns.

Richardson (1992), Papastefanou et a1. (1989), and Elstner et a1. document how lichens and mosses have been used successfully to monitor contamination by radioactive elements derived from atmospheric nuclear testing, orbital decay of nuclear-powered satellites, and accidents such as the one at the Chernobyl nuclear-powered electricity-generating station. Accumulation of ${ }^{137} \mathrm{Cs}$ and ${ }^{90} \mathrm{Sr}$ has been demonstrated and can be attributed to the relatively long half-lives of these isotopes and their chemical similarity to the essential macronutrients potassium and calcium, respectively.

Few radionuclide-uptake studies have been conducted on plant litter and mosses at North American nuclear sites. The purpose of this study was to make meaningful comparisons between the differential uptake of several

radionuclides in soil, sagebrush, plant litter, cryptogams, and small mammals. Much of the data presented in this document on radionuclide uptake of ${ }^{90} \mathrm{Sr}$, plutonium, ${ }^{99} \mathrm{Tc}$, and ${ }^{129} \mathrm{I}$ by mosses and plant litter may be some of the first of its kind. Some of the data presented in this paper were previously reported in Westinghouse Hanford Company documents by Landeen et al. (1984, 1985), Swanson et. al. (1988), and Johnson et al. (1991).

\section{MATERIALS AND METHODS}

Soil, sagebrush, plant litter, cryptogams, and small mammals were collected at 89 sample locations on the 200 East plateau area of the Hanford Site downwind from many ongoing waste management activities (Figures 2 and 3 ). Not all sample media were collected at each location and not all samples were analyzed for each radionuclide. Samples were collected from 1981 to 1986 to support site characterization and preoperational monitoring activities.

At each sample station, equivalent-volume soil plugs were collected at five points to make a composite sample. The five plugs were collected at a depth of from 0 to $2.5 \mathrm{~cm}$. One sample was collected adjacent to the station marker post and one was collected in each of the four compass directions. Leaves and twigs were clipped from sagebrush growing within a $10-\mathrm{m}$ radius of the station marker post. Plant litter was collected from underneath the canopies of the sampled sagebrush. Cryptogams were collected from within $10 \mathrm{~m}$ of each station marker post. Cryptogam species collected and analyzed in this study were identified by Dr. Larry St. Clair of Brigham Young University as a combination of two species of epigeic mosses, Tortula ruralis and Bryum sp., which are abundant in the Great Basin region of the western United States (Pearson and Rope 1987). Control samples for soil, sagebrush, litter, and cryptogams were collected several miles upwind and off the Hanford Site. 
Figure 2. Locations and Sample Station Numbers of Radioecology Sampling Stations.

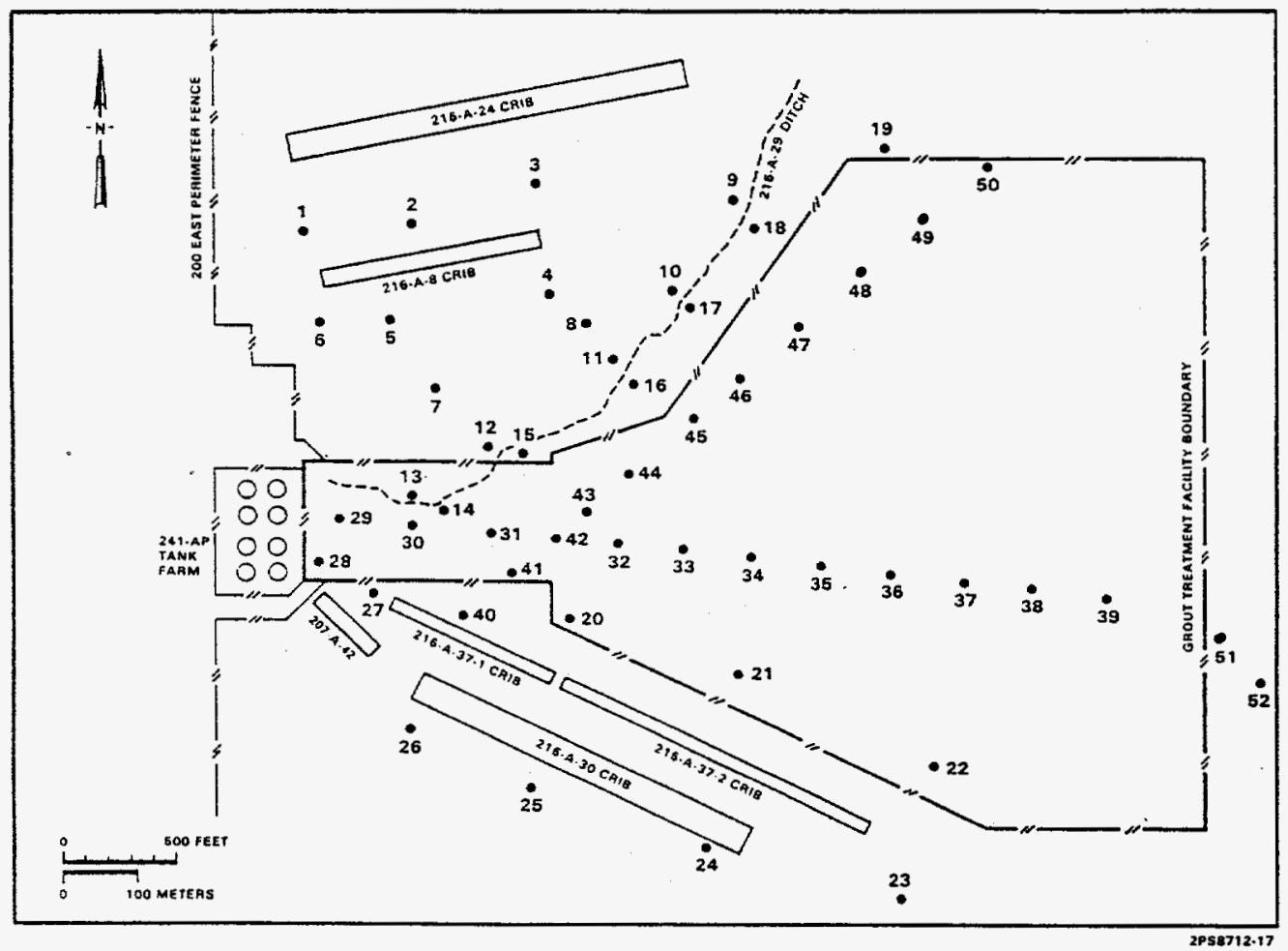

Figure 3. Locations and Sample Station Numbers of Radioecology Sampling Stations in Relation to the Wye Barricade.

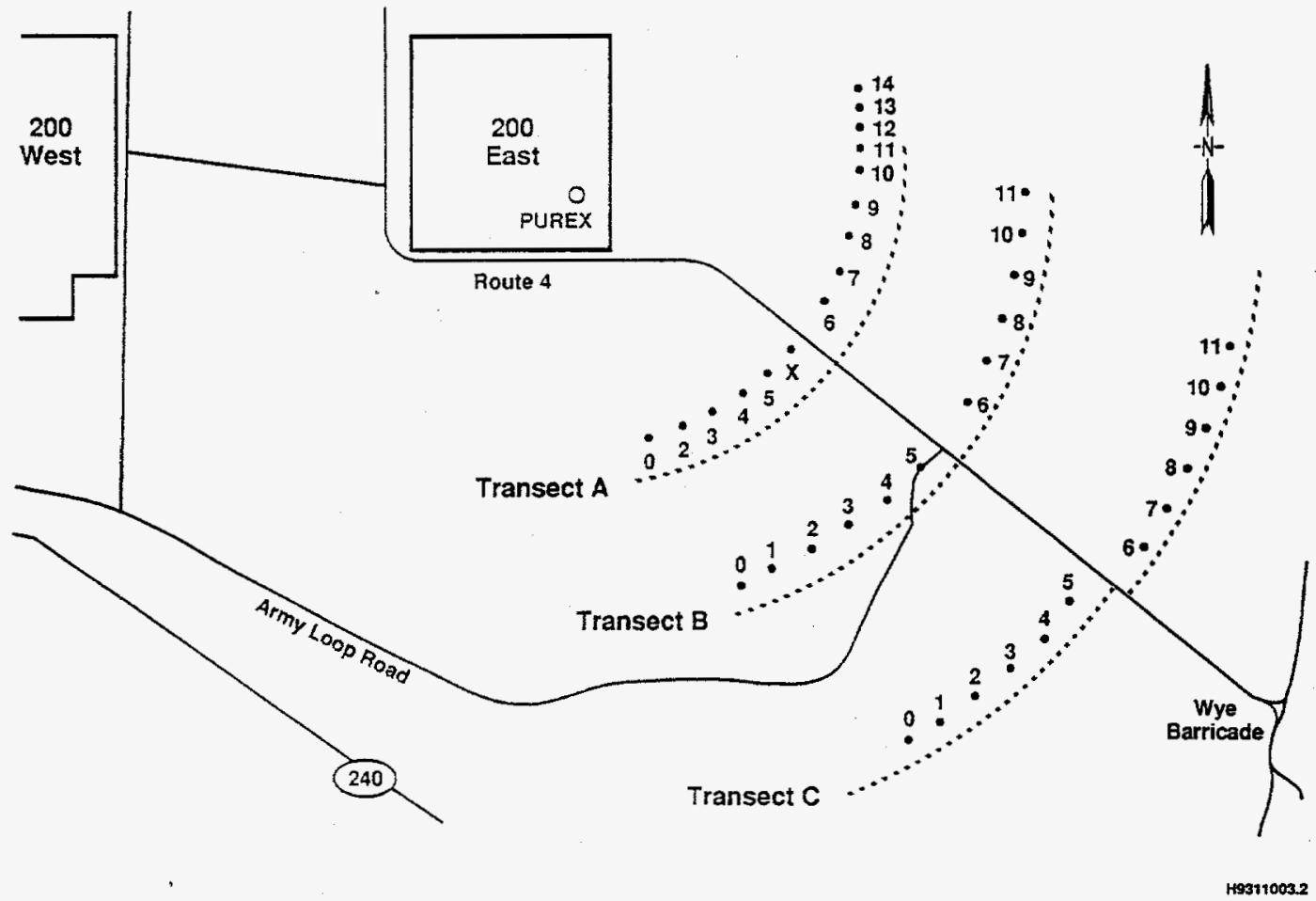


Small mammals were collected from selected sample stations using "Museum Special" snaptraps. A17 but 4 of the 33 small mammals collected were identified as Great Basin pocket mice (Perognathus parvus). The other four species were deer mice (Peromyscus maniculatus).

Samples were submitted to U.S. Testing Company in Richland, Washington, for radionuclide analysis.

\section{RESULTS}

\section{CRYPTOGAM ECOLOGY}

The cryptogams, collected and analyzed in this study were identified as terricolous (growing on soil) mosses (Tortula ruralis and Bryum sp.), which are relatively common on bare soil surfaces in western North American shrubsteppe environments.

\section{RADIONUCLIDE RESULTS}

Table 1 summarizes the average concentration values and other statistics for all the radionuclides in soil, sagebrush, plant litter, cryptogams, small mammals, and control samples. Tables A-1 through A-8 (Appendix A) contain all of the radionuclide values observed in all media during the study period.

Table 1. Average Radionuclide Concentrations in Various Environmental Media ( $\mathrm{pCi} / \mathrm{gm})$.

\begin{tabular}{|l|c|c|c|c|c|c|}
\hline \multicolumn{1}{|c|}{ Medium } & ${ }^{137} \mathrm{CS}$ & ${ }^{90} \mathrm{Sr}$ & ${ }^{99} \mathrm{TC}$ & ${ }^{129} \mathrm{I}$ & ${ }^{238} \mathrm{Pu}$ & ${ }^{238 / 239} \mathrm{pu}$ \\
\hline Soil & $2.30(86) \mathrm{a}$ & $0.41(59) \mathrm{a}$ & $0.99(12) \mathrm{a}$ & $-0.14(16) \mathrm{a}$ & $0.0001(29) \mathrm{a}$ & $0.014(53) \mathrm{a}$ \\
\hline Sagebrush & $1.08(88) \mathrm{a}$ & $0.57(48) \mathrm{a}$ & $1.99(6) \mathrm{a}$ & $0.34(\mathrm{ab})$ & $0.025(5) \mathrm{a}$ & $0.060(15) \mathrm{a}$ \\
\hline Litter & $14.05(67) \mathrm{c}$ & $1.52(18) \mathrm{b}$ & $1.98(12) \mathrm{a}$ & $0.07(14) \mathrm{ab}$ & $0.002(3) \mathrm{a}$ & $0.047(3) \mathrm{a}$ \\
\hline Cryptogam & $8.51(64) \mathrm{b}$ & $1.39(18) \mathrm{b}$ & $0.71(5) \mathrm{a}$ & $0.32(15) \mathrm{b}$ & $0.028(3) \mathrm{a}$ & $0.013(3) \mathrm{a}$ \\
\hline
\end{tabular}

Note: Values are expressed as mean (number of samples). Values within a column followed by the same letter are not significantly different $(p<0.05)$ (Tukey multiple comparison procedure).

Mean values of ${ }^{137} \mathrm{Cs}$ were $1.08 \mathrm{pCi} / \mathrm{gm}$ in sagebrush, $2.30 \mathrm{pCi} / \mathrm{gm}$ in soil, $14.05 \mathrm{pCi} / \mathrm{gm}$ in $\mathrm{plant}$ litter, and $8.51 \mathrm{pCi} / \mathrm{gm}$ in cryptogams. Mean values in small mammals were $0.14 \mathrm{pCi} / \mathrm{gm}$ for ${ }^{137} \mathrm{Cs}$ and $0.07 \mathrm{pCi} / \mathrm{gm}$ for ${ }^{90} \mathrm{Sr}$. The highest ${ }^{137} \mathrm{Cs}$ value $(900.0 \mathrm{pCi} / \mathrm{gm})$ was found in a cryptogam and the highest ${ }^{90} \mathrm{Sr}$ value $(5.72 \mathrm{pCi} / \mathrm{gm})$ was detected in $\mathrm{plant}$ litter. Figure 4 shows the mean concentrations for ${ }^{137} \mathrm{Cs}$ and ${ }^{90} \mathrm{Sr}$ in a 11 media. The highest mean values for ${ }^{99}$ Tc were found, in descending order in sagebrush, litter, soil, and mosses. Mean values for ${ }^{238} \mathrm{Pu}$, ${ }^{239 / 240} \mathrm{Pu}$, and ${ }^{129} \mathrm{I}$ in al media did not exceed $0.35 \mathrm{pCi} / \mathrm{gm}$. Mean concentration values for ${ }^{129} \mathrm{I}$ were negative in all media with the exception of sagebrush. Significant differences between radionuclide levels in all media are presented in Table 1. 
WHC-EP-0771

Figure 4. Mean Concentrations of ${ }^{137} \mathrm{Cs}$ and ${ }^{90} \mathrm{Sr}$ in All Media.

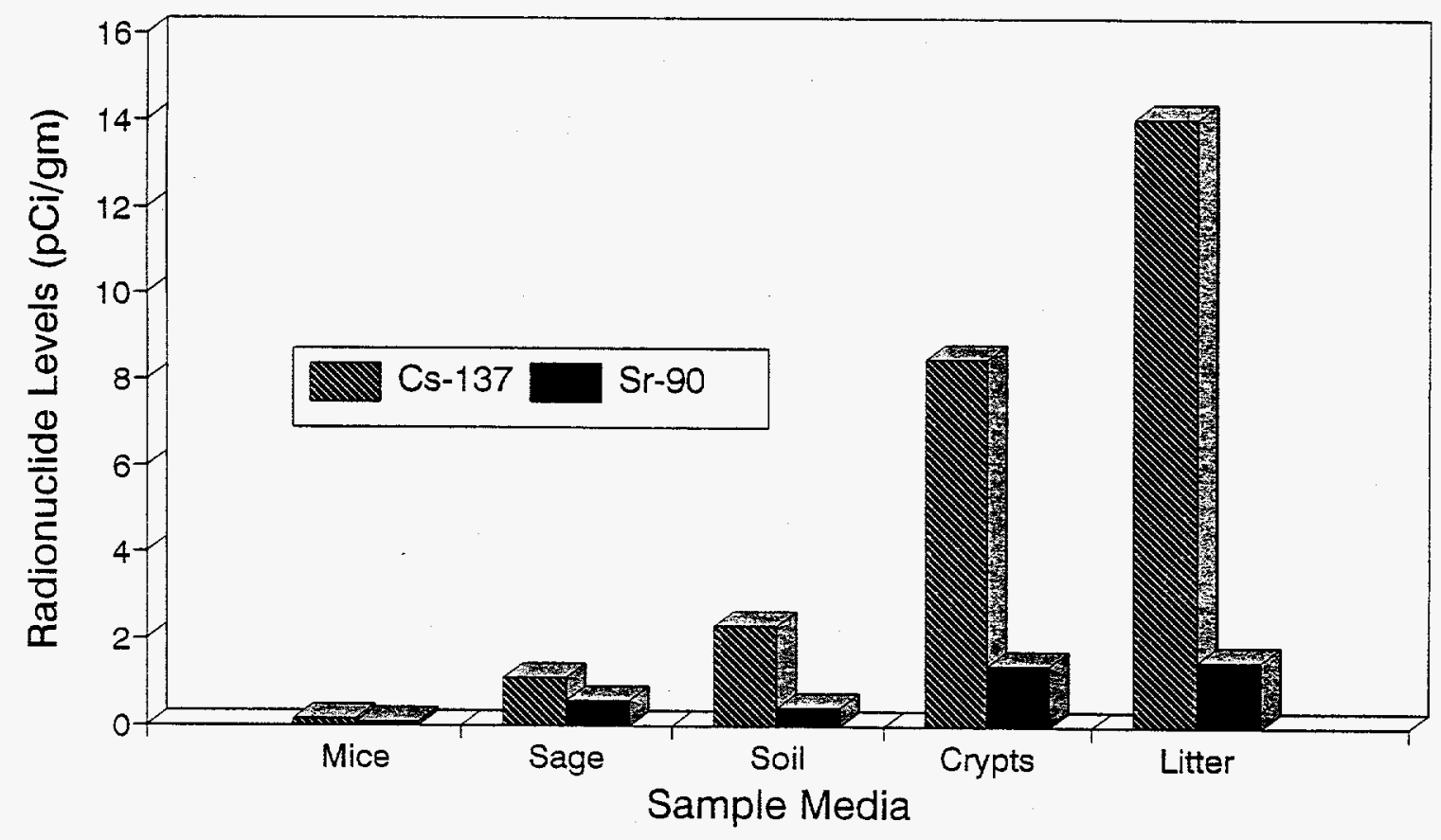

Table 2. Mean Concentration Ratios for ${ }^{137} \mathrm{Cs}$ and ${ }^{90} \mathrm{Sr}$ ( $\mathrm{pCi} / \mathrm{gm}$ sample media/pCi/gm soil).

\begin{tabular}{|l|c|c|c|c|c|c|}
\hline & \multicolumn{2}{|c|}{ Sagebrush } & \multicolumn{2}{c|}{ Litter } & \multicolumn{2}{c|}{ Cryptogams } \\
\hline & ${ }^{137} \mathrm{Cs}$ & ${ }^{90} \mathrm{Sr}$ & ${ }^{137} \mathrm{Cs}$ & ${ }^{90} \mathrm{Sr}$ & ${ }^{137} \mathrm{Cs}$ & ${ }^{90} \mathrm{Sr}$ \\
\hline Maximum & 12.80 & 145.50 & 35.61 & 7.2 & 84.11 & 6.09 \\
\hline Minimum & 0.00 & 0.02 & 0.48 & 0.19 & 0.73 & 0.91 \\
\hline Mean & 0.85 & 4.56 & 8.40 & 2.74 & 6.41 & 2.67 \\
\hline
\end{tabular}


Concentration ratios of sagebrush radionuclide levels to soit radionuclide concentrations were calculated for ${ }^{99} \mathrm{TC},{ }^{137} \mathrm{Cs},{ }^{90} \mathrm{Sr}$, and ${ }^{129} \mathrm{I}$. Concentration ratios ranged from 0.65 to 13.31 for ${ }^{93} \mathrm{Tc}, 0.00$ to 12.79 for ${ }^{137} \mathrm{Cs}, 0.02$ to 145.50 for ${ }^{90} \mathrm{Sr}$, and 0.01 to 5.22 for ${ }^{129} \mathrm{I}$. The mean values for these concentration ratios in sagebrush are presented in Table 2 and shown graphically in Figure 5 .

Figure 5. Mean Concentration Ratios of Selected Radionuclides in Sagebrush.

$$
\begin{aligned}
& \text { Mean Concentration Ratios in Sagebrush } \\
& \text { (pCi/gm sample media/pCi/gm soil) }
\end{aligned}
$$

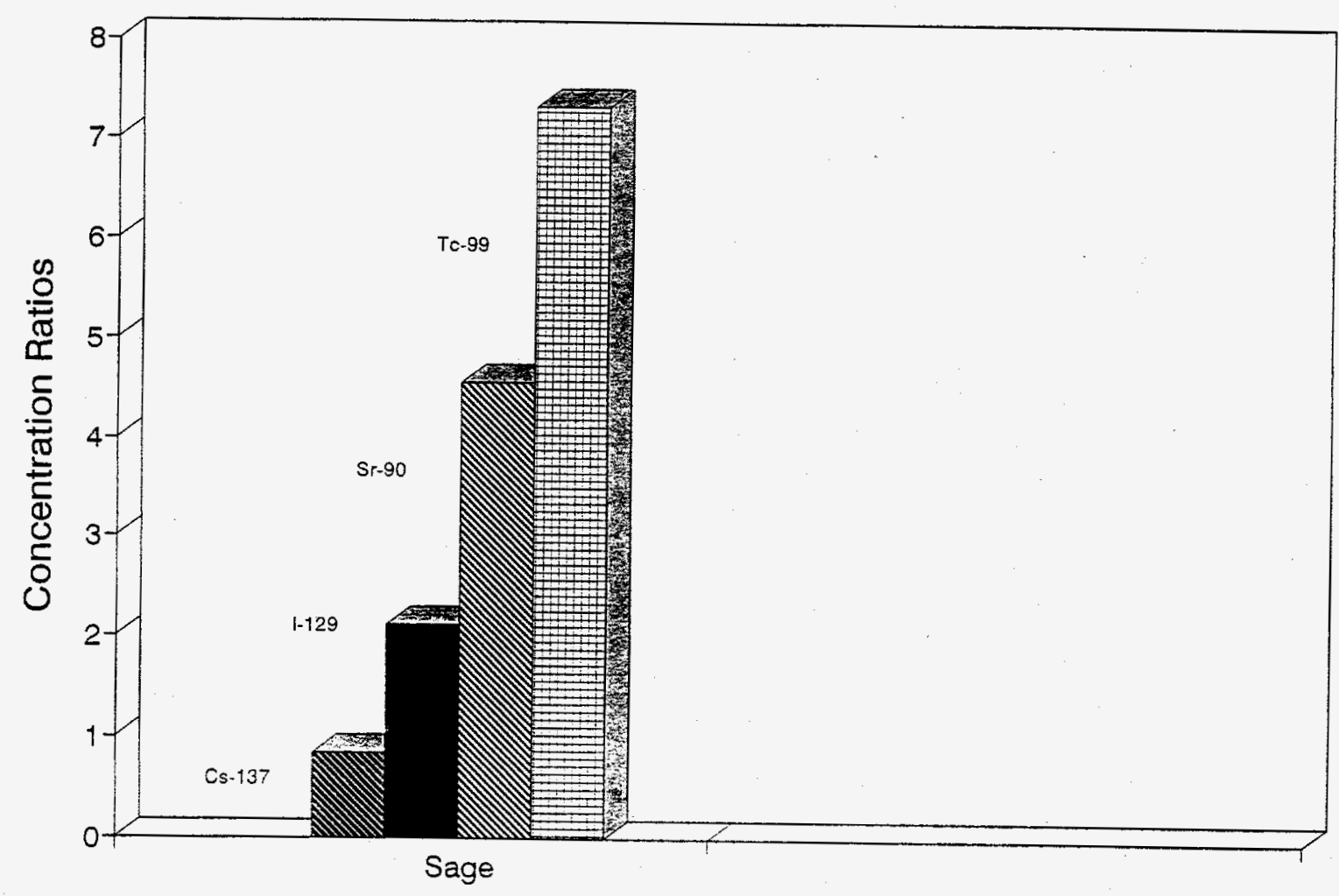




\section{DISCUSSION}

The radionuclide concentrations observed in this study were collected by May 2, 1986, before the nuclear reactor accident at Chernobyl in the Ukraine, which occurred on Aprit 26, 1986. Approximately $81 \mathrm{M} \mathrm{Ci}$ of radioactivity (primarily cesium) were released to the atmosphere as a result of the accident. The first indication of fallout in Washington State from the Chernobyl release was detected on May 5, 1986 (PNL 1987).

Two radioactive release incidents may have affected some of the samples, resulting in elevated values. The first consisted of releases of radioactive material from October to November of 1984 at the 207-A-42 Diversion Basin, which is proximal to a number of the sample locations. Most of the activity was attributed to short-lived radionuclides such as ${ }^{106} \mathrm{Ru},{ }^{95} \mathrm{Zr}$, and ${ }^{95} \mathrm{Nb}$. The second incident occurred at the 241-C-151 Diversion Box in January 1985. An estimated $1.4 \mathrm{Ci}$ of ${ }^{90} \mathrm{Sr}$ and $0.02 \mathrm{Ci}$ of ${ }^{137} \mathrm{Cs}$ were released over a rather widespread area downwind of the source term, which included a portion of the sampled area (Elder et a1. 1986). Contamination attributable to these two incidents appeared to be detectable in the sample results.

SOIL

Concentration levels for all the radionuclides analyzed were lower in soil than all other media, which suggests that relying only on soil samples to monitor radionuclides and other pollutants might not give an accurate assessment of environmental conditions. This is particularly true when soil samples are collected from areas where air deposition is the only source of contamination. The highest mean concentration value observed in soil during this study was ${ }^{137} \mathrm{Cs}$ with a mean value of $2.3 \mathrm{pCi} / \mathrm{gm}$.

\section{SAGEBRUSH}

Concentrations for a 11 radionuclides with the exception of ${ }^{99} \mathrm{Tc}$ and ${ }^{129} \mathrm{I}$ were the lowest in sagebrush of a 71 the media sampled. "Tc has a long half1 ife and a fission yield approximately equivalent to that of ${ }^{90} \mathrm{Sr}$ or ${ }^{137} \mathrm{Cs}$ (Wildung et al. 1979). The high fission yield and long half-life of ${ }^{99} \mathrm{TC}$ ensure that it will be found at higher levels than ${ }^{129} \mathrm{I}$ because of worldwide nuclear testing. Studies at the Hanford Site (Routson and Cataldo 1977 and Wildung et al. 1974, 1976, and 1977) and el sewhere (Gast 1975) have shown technetium to be readily available for plant uptake. Cataldo et al. (1978) documented how plants effectively removed up to 90 percent of the technetium at soil concentrations of $0.1 \mu \mathrm{g} / \mathrm{g}$.

Concentration ratios for ${ }^{99} \mathrm{TC}$ in this study ranged from 0.65 to 13.31 . In the studies mentioned earlier, concentration ratios for technetium ranged from 100 to 1000 (Cataldo 1979). " 129 I concentration ratios ranged from 0.01 to 5.22. This is comparable to other Hanford Site studies (Cline and Klepper 1975) that showed concentration ratios for iodine ranging from 0.53 to 1.25 in agronomic plants grown in Ritzville soil. Iodine concentration ratios observed in Hanford Site studies of cheatgrass and tumbleweeds showed values ranging from 1.0 to 4.0 in cheatgrass and 6.0 to 13.0 in tumbleweeds

(Cataldo 1979). 
The ${ }^{137} \mathrm{Cs}$ concentration ratios in sagebrush reported here are somewhat higher than those found in trees (Landeen and Mitche11 1986) and cheatgrass and tumbleweeds (Cataldo et al. 1978 and Routson 1986) during previous radionuclide uptake studies conducted at the Hanford Site. In these Hanford Site studies, concentration ratios for ${ }^{137} \mathrm{C} S$ never exceed 1.0 . However, in a study by Garten et a1. (1975) at Savannah River, concentration ratios for ${ }^{137} \mathrm{Cs}$ in roots, leaves, and twigs from wax myrtle and alder trees usually exceeded 1.0. In these Hanford Site studies, concentration ratios were higher for ${ }^{90} \mathrm{Sr}$ than for ${ }^{137} \mathrm{Cs}$, which is the same trend observed in the present study.

\section{LITTER}

Mean concentration values in litter were higher than the corresponding soil values for all of the radionuclides and in most cases were higher than the sagebrush concentration values. ${ }^{99} \mathrm{Tc}$ concentrations in this study were the highest in sagebrush $(2.25 \mathrm{pCi} / \mathrm{gm})$ and 1 itter $(2.02 \mathrm{pCi} / \mathrm{gm})$ compared to $0.87 \mathrm{pCi} / \mathrm{gm}$ in mosses. These results were similar to data published by Garten et a1. (1985) from studies at DOE's Oak Ridge National Laboratory (ORNL) in Tennessee. Concentrations of ${ }^{99} \mathrm{TC}$ in forest $1 \mathrm{itter}$ and surrounding vegetation were greater than concentrations found in the $0.5-\mathrm{cm}$ zone of the soil.

Other studies conducted at ORNL [Witherspoon (1964) and Witkamp and Frank (1964)] analyzed tree litter concentrations of ${ }^{137} \mathrm{Cs}$ and ${ }^{134} \mathrm{Cs}$. Both studies documented the rapid passage of cesium from the poplar and white oak trees to leaf litter and indicated that leaf fall doubled the amount of ${ }^{137} \mathrm{Cs}$ on the forest floor and increased the amount of ${ }^{137} \mathrm{Cs}$ in litter fifteen-fold.

\section{SMALL MAMMALS}

Levels of ${ }^{137} \mathrm{Cs}$ and ${ }^{90} \mathrm{Sr}$ did not exceed $0.70 \mathrm{pCi} / \mathrm{gm}$ in any small mammals collected in this study. Other studies at the Hanford Site (Paine et al. 1979, Landeen and Mitchel1 1982, and Gano 1979) have documented elevated levels of radionuclides in pocket mice that reside on waste sites. Small burrowing mammals have also been documented with elevated radionuclide levels at other DOE sites (Arthur and Markham 1983, Arthur et a1. 1986, Garten 1980, and Winsor and Whicker 1980). Mihok et al. (1989) observed elevated levels of ${ }^{137} \mathrm{Cs}$ in red-backed voles (Clethrionomys gapperi) in Canada following the Chernobyl accident. The elevated ${ }^{137} \mathrm{Cs}$ concentrations found in the voles was attributed to the consumption of fungi, which are a major part of their diet. Great Basin pocket mice are classified as granivores (seed eaters) and no documentation exists that would indicate that pocket mice consume lichens, mosses, or fungi. Kritzman (1974) indicated that vegetation and insects sometimes compose a small part of the diet of pocket mice at the Hanford site. However, it does not appear that the higher 1 evels of ${ }^{137} \mathrm{Cs}$ and ${ }^{90} \mathrm{Sr}$ found in litter and cryptogams is being incorporated into the small-mammal community.

\section{CRYPTOGAMS (MOSSES)}

Mosses not only are good air pollution monitors, but in some ecosystems contribute a large part of the total biomass and productivity. Mosses grow in large carpets on the ground and have more surface area than other plants to intercept particulate deposition and rain (Manning and Feder 1980). Nutrient cycling in many ecosystems is dependent on mosses, which also occur in the 
food chains of a great many invertebrate and vertebrate animals (S1ack 1988). Mosses also play important roles as pioneer species in habitats that may have been severely disturbed.

Mosses absorb pollutants from the air and from precipitation. Nutrients are absorbed as particulates and in solution by interception of atmospheric deposition because the rhizoidal attachment to their substrate does not function as a root system. Mosses possess leaves and stems but the leaves are inserted on the stem in such a way that radial symmetry is created. Physiological activity in mosses depends on water content, which varies passively with environmental conditions. Under moderate to high temperatures and non-saturated atmospheric conditions, mosses become inactive. For example, species that grow in arid locations such as the Hanford site can survive years of desiccation, whereas most aquatic species can only survive a few hours of desiccation (Nash and Egan 1988).

The ${ }^{137} \mathrm{Cs}$, ${ }^{90} \mathrm{Sr}$, and ${ }^{238} \mathrm{Pu}$ concentrations reported in this study, including control values, were generally higher in mosses than in the other media studied. These results are similar to lichen studies conducted at the Idaho National Engineering Laboratory in a shrub-steppe environment (Rope and Pearson 1990) and (Pearson and Rope 1987), which indicated that many trace elements were significantly higher in lichens than in soil, sagebrush, and grass. The authors concluded that lichens should be preferable to soil for monitoring the biologically available fraction of atmospheric sources of trace elements, especially those with a naturally high concentration in soil.

A review of the literature determined that most of the research about radionuclide uptake by mosses has been conducted in Great Britain, Scandinavia, and eastern Europe, utilizing sphagnum and feather mosses. Much of the published literature is from surveys of radioactive fall-out resulting from nuclear weapons tests.

Accumulation of ${ }^{137} \mathrm{Cs}$ and ${ }^{90} \mathrm{Sr}$, in particular, has been demonstrated and can be attributed to their relatively long half-life and their chemical similarity to the essential macronutrients potassium and calcium. Because cesium is an analog for potassium, it may be taken up by plants as a surrogate using the same transport mechanisms (Tuominen and Jaakkola 1973). Sawidis and Heinrich (1992) and Papastefanou et al. (1992), in studies in northern Greece, reported ${ }^{37} \mathrm{Cs}$ levels in 7 ichens and mosses, including the moss species Tortula ruralis, which was also collected in our study. Both lichens and mosses showed elevated levels of ${ }^{137} \mathrm{Cs}$ for two to five years after the Chernobyl accident. In their study, 1 ichens showed consistently higher levels of ${ }^{137} \mathrm{Cs}$ than did the mosses collected in the same habitats. Mihok et a1. (1989) collected and analyzed fungi (mushrooms), mosses, and 1 ichens for ${ }^{137} \mathrm{Cs}$ in a spruce bog forest in Manitoba, Canada. They found that mushrooms had significantly higher levels of ${ }^{137} \mathrm{Cs}$ than 1 ichens and mosses. Mosses (Pseudoscleropodium purum and Hypnum cupressiforme) were collected and analyzed for radionuclide content at various distances from the Sellafield nuclear processing $p l a n t$ in Great Britain. ${ }^{137} \mathrm{Cs}$ and ${ }^{129} \mathrm{I}$ concentrations in these mosses declined with distance from the plant (Sumerling 1984).

Bovard and Grauby (1967) advocated using sphagnum mosses to monitor radionuclides because of their demonstrated capacity to accumulate ${ }^{137} \mathrm{Cs}$. Witkamp and Frảnk (1967) supplied ${ }^{137} \mathrm{Cs}$ in simulated rain in a pine forest in Tennessee and showed that tussocks of the moss Dicranum scoparium retained 96 percent of the applied radioactivity compared with 72 percent retention by 
rosettes of an angiosperm, Potentilla canadensis. Rickard's study in the Washington State (Rickard 1967) al so found that mosses showed higher accumulations of ${ }^{137} \mathrm{Cs}$ than forest-floor litter or soil.

As previously stated, the high accumulation capacity and widespread distribution of mosses indicate their potential use as monitors of airborne sources of radionuclides. Mosses would not have much value in assessing the importance of soil contamination on, for example, uptake by food crops. Interspecies differences in uptake related to rooting depths and general morphology of other plants indicate that caution must be exercised in drawing conclusions about contamination based on vegetation samples. This problem appears to be less important for monitoring radionuclides in mosses, which have been shown to reflect temporal and spatial differences in deposition (Burton 1986).

\section{SUMMARY}

Soil, sagebrush, plant litter, cryptogams, and smali mammals on the Hanford Site were analyzed for several radionuclides. The highest radionuclide concentrations observed were for ${ }^{137} \mathrm{Cs},{ }^{90} \mathrm{Sr}$, and ${ }^{99} \mathrm{Tc}$ in 1 itter and cryptogams. Radionuclide concentrations in soil, sagebrush, and small mammals were comparatively lower than in litter and cryptogams. This suggests that litter and cryptogams are probably better indicators of environmental quality related to airborne contamination than vegetation or soil samples for some radionuclides. Augmenting a sampling program at nuclear facilities with samples of litter and cryptogams may provide a more accurate representation of environmental uptake and/or contamination. Similar results might also be obtained in testing for levels of heavy metals or other pollutants. Studies need to be conducted at other nuclear facilities in North America to determine if cryptogams and plant litter should be sampled and analyzed for environmental contaminants.

\section{REFERENCES}

Arthur, W. J. and O.D. Markham, 1983, Small Mammals as a Radionuclide. Transport Vector at a Solid Radioactive Waste Disposal Area, Ecological Society of America Annual Meeting, Pennsylvania State University, University Park, Pennsylvania.

Arthur, W. J., 0. D. Markham, C. R. Groves, B. L. Keller, and D. K. Halford, 1986, "Radiation Dose to Small Mammals Inhabiting a Solid Radioactive Waste Disposal Area," Journal of Applied Ecology, vol. 23, pp. 13-26.

Barclay-Estrup, P. and R. J. K. Rinne, 1978, "Lead and Zinc Accumulation in Two Feather Mosses in Northwestern Ontario, Canada, "Oikos, vol. 30, pp. 106-108.

Bovard, P. and A. Grauby, 1967, "The Fixation of Radionuclides From Atmospheric Fallout in Peat-bog Sphagnum sp., Polytrichum and Myriophyllum," Radioecological Concentration Processes, B. Aberg and F. P. Hungate, editors, Pergamon Press, Oxford, England. 
Burton, A, 1986, Biological Monitors of Environmental Contamination (Plants), MARC Report No. 32, King's College Monitoring Assessment Centre, London, England.

Cataldo, D. A., R. C. Routson., D. Paine and T. R. Garland, 1978, Relationship Between Properties of Hanford Area Soils and the Availability of Cs-134 and Sr-85 for Uptake by Cheatgrass and Tumbleweed, PNL-2496, Pacific Northwest Laboratory, Richland, Washington.

Cataldo, D. A., 1979, Behavior of Technetium and Iodine in a Hanford Sand and Associated Subsoi7: Influence of Soil Aging on Uptake by Cheatgrass and Tumbleweed, PNL-2740, Pacific Northwest Laboratory, Richland, Washington.

Cirrincione, D. A. and D. B. Costain, 1990, Rocky Flats Plant site Environmental Report, January--December 1990, RFP-ENV-90, EG and G Rocky Flats, Inc., Golden, Colorado.

Cline, J. F. and E. W. Klepper, 1975, "Iodine-125 Accumulation in PIant Parts: Influence of Water Use Rate and Stable Iodine Content of Soil," Health Physics, vol. 28, pp. 801-804.

Cummins, C. L., D. K. Martin, and J. L. Todd, 1989, Savannah River Environmental Report for 1989, Volume 1, DOE/ENV/1063033, Westinghouse Savannah River Company, Aiken, South Carolina.

Elder, R. E., A. W. Conklin, D. D. Brekke, G. W. Egert, and W. L. Osborne, 1986, Rockwell Hanford Operations Environmental Surveillance Annual Report, Calendar Year 1985, RHO-HS-SR-85-13P, Rockwe11 Hanford Operations, Richland, Washington.

Elstner, E. F., R. Fink, W. Holl, E. Lengfelder, and H. Ziegler, 1987, "Natural and Chernobyl-caused Radioactivity in Mushrooms, Mosses and Soil-Samples of Defined Biotops in SW Bavaria," Oecologia, vol. 73, pp. 553-558.

Folkeson, L., 1979, "Interspecies Calibration of Heavy-metal Concentrations in Nine Mosses and Lichens: Applicability to Deposition Measurements," Water, Air, and Soil Pollution, vol. 11, pp. 253-260.

Gano, K. A., 1979, Analysis of Sma7l Mammal Populations Inhabiting the Environs of a Low-Level Radioactive Waste Pond, PNL-2479, Pacific Northwest Laboratory, Richland, Washington.

Garner, J. A. and J. H. Jenkins, 1991, "High Radiocesium Levels in Granite Outcrop Vegetation and Reductions Through Time," Health Physics, vol. 60, no. 4 , pp. 533-538.

Garten, C. T., Jr., L. A. Briese, Jr., R. R. Sharitz, and J. B. Gentry, 1975, Seasonal Variation in Radiocesium Concentrations in Three Tree Species, in Mineral Cycling in Southeastern Ecosystems, CONF-740513, U.S. Department of Energy, National Technical Information Center, Oak Ridge, Tennessee. 
Garten, C. T., Jr., 1981, Field Determination of Cs-137 Assimilation Efficiencies in Wild Cotton Rats (Sigmodon hispidus), Health Physics, Volume 38,

Garten, C. T., Jr., E. A. Bondietti, B. T. Walton, and C. S. Tucker, 1985, Long-Term Fate of Technetium-99 in Forest Environments, Environmental Sciences Division Annual Progress Report, ORNL-6140, Oak Ridge National Laboratory, Oak Ridge, Tennessee.

Gast, R. G., 1975, The Behavior of Technetium-99 in Soils and Plants, CO0-2447-1, U.S. Department of Energy, National Technical

Information Service, Springfield, Virginia.

Glooschenko, W. A. and J. A. Capobianco, 1978, "Metal Content of Sphagnum Mosses From Two Northern Canadian Bog Ecosystems, "Water, Air and Sojl Pollution, Volume 10 ,

Groet, S. S., 1976, "Regional and Local Variations in Heavy Metal Concentrations of Bryophytes in the Northeastern United States," oikos, Volume 27 ,

Hakonson, T. E. and E. S. GTadney, 1981, Biological Intrusion of Low-Level Waste Trench Covers, presented at Materials Research Society Symposium on the Technical Basis for Nuclear Waste Management, November 17-19, 1981, Boston, Massachusetts.

Hofmann, W., N. Attarpour, H. Lettner, and R. Turk, 1993, "Cesium-137 Concentrations in Lichens Before and After the Chernobyl Accident," Health Physics, Volume 64,

Hoffman, G. R., 1974, "The Influence of a Paper Pulp Mill on the Ecological Distribution of Epiphytic Cryptogams in the Vicinity of Lewiston, Idaho and Clarkston, Washington, "Environmental Pollution, Volume 7 ,

Huckabee, J. W., 1973, "Mosses: Sensitive Indicators of Airborne Mercury Pollution," Atmos. Environ., vol. 7, pp. 749-754.

Hunter, R. B., 1992, Status of the Flora and Fauna on the Nevada Test Site, 1988, Results of Continuing Basic Environmental Monitoring, January--December 1988, DOE/ENV/1063029, Reynolds Electrical and Engineering $C_{0} .$, Inc., Las Vegas, Nevada.

Jahns, H. M., 1988, "The lichen Thallus," Handbook of Lichenology, M. Galun, editor, Volume 1, CRC Press, Boca Raton, Florida.

Johnson, A. R., R. F. Brich, L. P. Diediker, J. J. Dorian, S. M. Mckinney, C. J. Perkins, and J. W. Schmidt, 1993, Monitoring the Contro7 of Biological Related Spread of Radionuclides at Hanford Site Operations Facilities, WHC-SA-1820-VA, presented at the 38th Annual Health Physics Society Meeting, Anaheim, California, July 11-15.

Klepper, E. W., 1976, Radionuclide Uptake by Wheat Plants with Time After Amendment to So il, BNWL-SA-5682, Pacific Northwest Laboratory, Richland, Washington. 
Kritzman, E. B., 1974, "Ecological Relationships of Peromyscus maniculatus and Perognathus parvus in Eastern Washington," Journal of Mammalogy, vol. 55, no. 1, pp. 172-188.

Landeen, D. S. and R. M. Mitche11, 1982, The Role of Burrowing Activities of the Great Basin Pocket Mouse (Perognathus parvus) in the Dispersal of Radionuclides on a Decommissioned Pond, RHO-HS-SA-1OP, Rockwel1 Hanford Operations, Richland, Washington.

Landeen, D. S., J. G. Leitz, L. J. Maas, R. M. Mitche11, K. R. Price, and M. J. Sula, 1984, Preliminary Purex Preoperational Radiological Status Report, SD-CP-PRS-001, Rockwe 11 Hanford Operations, Richland, Washington.

Landeen, D. S., R. M. Mitche11, K. R. Price, M. J. Shula, M. S. Trevathan, and L. J. Maas, 1985, PUREX Preoperational Environmental Survey Report, RHO-RE-ST-45 P, Rockwe 11 Hanford Operations, Richland, Washington.

Landeen, D. S. and R. M. Mitchel1, 1986, "Radionuclide Uptake By Trees at a Radwaste Pond in Washington State," Health Physics, vol. 50, no. 6, pp. 769-774.

Manning, W. J. and W. A. Feder, 1980, Biomonitoring Air Pollutants With Plants, Applied Science, London, England.

Mattson, S. and K. Liden, 1975, "Cesium-137 in Carpets of the Forest Moss Pleurozium schriberi, 1961-1973," Oikos, Volume 26, pp. 323-327.

Mihok, S., B. Schwartz, and A. M. Wiewel, 1989, "Bioconcentration of Fallout Cesium-137 by Fungi and Red-Backed Voles," Health Physics, vol. 57, pp. 959-966.

Nash, T. H., III, and R. S. Egan, 1988, "The Biology of Lichens and Bryophytes," Lichens, Bryophytes and Air Quality, T. H. Nash and V. Wirth, editors, J. Cramer, Berlin, Germany.

Nifontova, M. G. and V. N. Aleksashenko, 1992, "Strontium-90, Cesium-134 and Cesium-137 Concentration in Fungi, Lichens, and Mosses in an Area Adjacent to the Chernobyl Nuclear Power Plant," Ekologiya, vol. 0, no. 3, pp. 26-30.

Paine, D., K. R. Price, and R. M. Mitchell, 1979, Evaluation of a Decommissioned Radwaste Pond, RHO-SA-99, Rockwell Hanford Operations, Richland, Washington.

Papastefanou, C., M. Manolopoulou, and T. Sawidis, 1989, "Lichens and Mosses: Biological Monitors of Radioactive Fallout from Chernobyl Reactor Accident," Journal of Environmental Radioactivity, vol. 9, pp. 199-207.

Papastefanou, C., M. Manolopoulou, and T. Sawidis, 1992, "Residence Time and Uptake Rates of Cesium-137 in Lichens and Mosses at Temperate Latitude (40 Degrees N), "Environmental Internationa 7, vol. 18, pp. 397-401. 
Pearson, L. C. and S. K. Rope, 1987, Lichens of the Idaho National Engineering Laboratory, DOE/ID-12110, U.S. Department of Energy, Idaho Operations Office, Idaho Falls, Idaho.

Pilegaard, K., L. Rasmussen, and H. Gydesen, 1979, "Atmospheric Background Deposition of Heavy Metals in Denmark Monitored by Epiphytic Cryptogams," Journal of Applied Ecology, vol. 16, pp. 843-853.

PNL, 1987, Environmental Monitoring at Hanford for 1986, PNL 6120, Pacific Northwest Laboratory, Richland, Washington.

Rickard, W. H., J. J. Davis, W. C. Hanson, and D.G. Watson, 1965, "Gammaemitting Radionuclides in Alaska Tundra Vegetation 1959, 1960, 1961," Ecology, vol. 46, pp. 352-356.

Rickard, W. H., 1967, "Accumulation of Cs-137 in Litter and Understory Plants of Forest Stands From Various Climatic Zones of Washington," Radioecological Concentration Processes, B. Aberg and F. P. Hungate, editors, Pergamon Press, Oxford, England.

Richardson, D. H. S., 1992, Pollution Monitoring with Lichens, Richmond Publishing Co. LTD, Slough, SL2 3RS, England.

Rope, S. K. and L. C. Pearson, 1990, "Lichens as Air Pollution Biomonitors in a Semiarid Environment in Idaho," The Bryologist, vol. 93, no. 1, pp. 50-61.

Routson, R. C., 1975, The Effect of Soil Concentration on the Tumbleweed Uptake of Sr-90 and Cs-137 From a Burbank Sand, BNWL-1905, Pacific Northwest Laboratory, Richland, Washington.

Routson, R. C. and D. A. Cataldo, 1978, "A Growth Chamber Study of the Affect of Soil Concentration and Plant Age in the Uptake of Sr and Cs by Tumbleweed," Community of Soil Science and Plant Analysis, Volume 9, pp. 215-229.

Sawidis, T. and G. Heinrich, 1992, "Cesium-137 Monitoring Using Lichens and Mosses From Northern Greece," Canadian Journal of Botany, vol. 70, no. 1, pp. 140-144.

Scanton, P. F., 1979, "Ecological Implications of Heavy Metal Contamination of Roadside Habitats, "Proceedings of the Thirty-Third Annual Conference Southeastern Association of Fish and Wildlife Agencies, Volume 33, pp. 315-330, October 21-24, Hot Springs, Arkansas.

Schmidt, J. W., A. R. Johnson, S. M. Mckinney, C. J. Perkins, and C. R. Webb, 1992, Westinghouse Hanford Company Environmental Survei 71 ance Annual Report Calendar Year 1991, WHC-EP-0573, Westinghouse Hanford Company, Richland, Washington.

Schmidt, J. W., A. R. Johnson, S. M. Mckinney, and C. J. Perkins, 1993, Westinghouse Hanford Company Operational Environmental Monitoring Annual Report, CY 1992, WHC-EP-0573-1, Westinghouse Hanford Company, Richland, Washington. 
Slack, N. G., 1988, "The Ecological Importance of Lichens and Bryophytes. In: Lichens, Bryophytes and Air Quality, T. H. Nash and V. Wirth, editors, pp. 23-54, Bibliotheca Lichenologica Vol 30. J.Cramer, Berlin, Germany.

Sumerling, T. J., 1984, "The Use of Mosses as Indicators of Airborne Radionuclides Near a Major Nuclear Installation," The Science of the Total Environment, vol. 35, pp. 251-265.

Svoboda, J., E. Hutchison-Benson, and H. W. Taylor, 1986, "Arctic Cushion plants as Fallout 'Monitiors', "Journal of Environmental Radioactivity, vol. 4, pp. 65-76.

Swanson, L. C., D. C. Weeks; S. P. Luttre11, R. M. Mitche11, D. S. Landeen, A. R. Johnson, and R. C. Roos, 1988, Grout Treatment Facility Environmental Baseline and Site Characterization Report, WHC-EP-0150, Westinghouse Hanford Company, Richland, Washington.

Talmage, S. S. and B. T. Walton, 1991, "Small Mammals as Monitors of Environmental Contaminants," Review Environmental Contamination Toxicology, vol. 119, pp. 47-145.

Thomas, D. J., B. Tracey, H. Marshall, and R. J. Nordstrom, 1992, "Arctic Terrestrial Ecosystem Contamination," Science of the Total Environment, vol. 122, no. 1-2, pp. 135-164.

Tuominen, Y., and T. Jaakkola, 1973, "Absorption and Accumulation of Mineral Elements and Radioactive Nuclides," The Lichens, V. Ahmadjian and M. E. Hale, editors, Academic Press, London, England.

Vaughan, B. E., 1978, Pacific Northwest Laboratory Annual Report for 1977 to the DOE Assistant Secretary for Environment Part 2 Ecological Sciences, PNL-2500 PT2, Pacific Northwest Laboratory, Richland, Washington.

Wallin, T., 1976, "Deposition of Airborne Mercury From Six Swedish ChlorAlkali Plants Surveyed by Moss Analysis, "Environmental Pollution, vol. 10, pp. 101-114.

Wildung, R. E., D. A. Cataldo, and T. R. Garland, 1976, Accumulation of Technetium From Soil by Plants, USERDA Report, BNWL-2000, Part 2, National Technical Information Service, Springfield, Virginia.

Wildung, R. E., T. R. Garland, and D. A. Cataldo, 1977, "Accumulation of Technetium From Soil by Plants," Health Physics, vol. 32, no. 4, pp. 314-317.

Wildung, R. E., K. M. McFadden and T. R. Garland, 1979, "Technetium Sources and Behavior in the Environment, "Journal on Environmental Quality, vol. 8, no. 2, pp. 156-161.

Winsor, T. F. and F. W. Whicker, 1980, "Pocket Gophers and Redistribution of Plutonium in the Soil, "Health Physics, vol. 39, pp. 257-262.

Witkamp, M. and M. L. Frank, 1964, "First Year of Movement, Distribution and Availability of $\mathrm{Cs}-137$ in the Forest Floor Under Tagged Tul ip Poplars," Radiation Botany, vol. 4, pp.485-495. 


\section{WHC-EP-0771}

Witkamp, M. and M. L. Frank, 1967, "Retention and Loss of Cesium-137 by Components of the Groundcover in a Pine (Pinus virginiana L.) Stand," Health Physics, vol. 13, pp. 985-990.

Witherspoon, J. P., 1964, "Cycling of Cesium-134 in White Oak Trees," Ecological Monographs, vol. 34 , no. 4.

Woodruff, R. K., R. W. Hanf, and R. E. Lundgren, 1993, Hanford Site

Environmental Report for Calendar Year 1992, PNL-8682, Pacific Northwest Laboratory, Richland, Washington. 
WHC-EP-0771

This page intentionally left blank. 
WHC-EP-0771

APPENDIX A

RADIONUCLIDE CONCENTRATION TABLES

A-1 
Table A-1. Mean Concentration Levels ( $\mathrm{pCi} / \mathrm{g}$ ) for all Media.

\begin{tabular}{|c|c|c|c|c|c|}
\hline Radionuclide & Soil & Sage & Litter & Lichen & Mice \\
\hline $\begin{array}{l}\text { Cs-137 } \\
\text { Range } \\
\text { St. Dev. } \\
\text { \# samples }\end{array}$ & $\begin{array}{c}2.3 \\
0.17-55.0 \\
6.11 \\
86\end{array}$ & $\begin{array}{c}1.07 \\
0.04-33.1 \\
3.52 \\
88\end{array}$ & $\begin{array}{c}14.05 \\
0.47-96.3 \\
16.67 \\
67\end{array}$ & $\begin{array}{c}15.26 \\
0.82-900 \\
111.1 \\
65\end{array}$ & $\begin{array}{c}0.14 \\
-0.15-0.7 \\
0.2 \\
32\end{array}$ \\
\hline $\begin{array}{l}\text { Sr-90 } \\
\text { Range } \\
\text { St. Dev. } \\
\text { \# samples }\end{array}$ & $\begin{array}{c}0.41 \\
0.04-2.21 \\
0.36 \\
59\end{array}$ & $\begin{array}{c}0.75 \\
0.01-5.82 \\
1.04 \\
57\end{array}$ & $\begin{array}{c}1.78 \\
0.05-5.72 \\
1.51 \\
31\end{array}$ & $\begin{array}{c}1.3 \\
0.20-4.78 \\
0.98 \\
28\end{array}$ & $\begin{array}{c}0.07 \\
0.02-0.16 \\
0.05 \\
9\end{array}$ \\
\hline $\begin{array}{l}\text { Tc-99 } \\
\text { Range } \\
\text { St. Dev. } \\
\text { \# samples }\end{array}$ & $\begin{array}{c}1.3 \\
0.13-9.44 \\
2.58 \\
12\end{array}$ & $\begin{array}{c}2.25 \\
0.34-7.22 \\
2.53 \\
6\end{array}$ & $\begin{array}{c}2.02 \\
-0.62-10.9 \\
3.81 \\
13\end{array}$ & $\begin{array}{c}0.87 \\
0.08-1.5 \\
0.56 \\
6\end{array}$ & \\
\hline $\begin{array}{l}\mathrm{I}-129 \\
\text { Range } \\
\text { St. Dev. } \\
\text { \# samples }\end{array}$ & $\begin{array}{c}-0.13 \\
-0.9-0.8 \\
0.42 \\
18\end{array}$ & $\begin{array}{c}0.34 \\
0.01-0.5 \\
0.18 \\
6\end{array}$ & $\begin{array}{c}-0.35 \\
-1.84-0.59 \\
0.76 \\
16\end{array}$ & $\begin{array}{c}-0.16 \\
-2.81-1.35 \\
1 \\
17\end{array}$ & \\
\hline $\begin{array}{l}\text { Pu-238 } \\
\text { Range } \\
\text { St. Dev. } \\
\text { \# samples }\end{array}$ & $\begin{array}{c}0.0001 \\
-0.004-0.00 \\
0.001 \\
29\end{array}$ & $\begin{array}{c}0.04 \\
0.0-0.20 \\
0.09 \\
5\end{array}$ & $\begin{array}{c}0.003 \\
0.001-0.004 \\
0.002 \\
3\end{array}$ & $\begin{array}{c}0.05 \\
0.04-0.07 \\
0.017 \\
3\end{array}$ & \\
\hline $\begin{array}{l}\text { Pu-239/240. } \\
\text { Range } \\
\text { St. Dev. } \\
\text { \# samples }\end{array}$ & $\begin{array}{c}0.024 \\
0.005-0.1 \\
0.025 \\
53\end{array}$ & $\begin{array}{l}0.11 \\
0.0-1.51 \\
0.39 \\
15\end{array}$ & $\begin{array}{c}0.047 \\
0.03-0.07 \\
0.021 \\
3\end{array}$ & $\begin{array}{c}0.013 \\
0.00-0.03 \\
0.015 \\
3\end{array}$ & \\
\hline $\begin{array}{l}\text { Control Cs-137 } \\
\text { Range } \\
\text { St. Dev. } \\
\text { \# samples }\end{array}$ & $\begin{array}{c}0.27 \\
0.03-0.84 \\
0.38 \\
4\end{array}$ & $\begin{array}{c}0.09 \\
0.06-0.14 \\
0.04 \\
3\end{array}$ & $\begin{array}{c}0.37 \\
0.22-0.66 \\
0.25 \\
3\end{array}$ & $\begin{array}{c}2.56 \\
2.42-2.85 \\
0.25 \\
3\end{array}$ & \\
\hline $\begin{array}{l}\text { Control Sr-90 } \\
\text { Range } \\
\text { St. Dev. } \\
\# \text { samples }\end{array}$ & $\begin{array}{c}0.21 \\
0.16-0.27 \\
0.08 \\
2\end{array}$ & $\begin{array}{c}0.15 \\
0.06-0.32 \\
0.15 \\
3\end{array}$ & $\begin{array}{c}0.41 \\
0.18-0.76 \\
0.31 \\
3\end{array}$ & $\begin{array}{c}0.87 \\
0.66-1.09 \\
0.3 \\
2\end{array}$ & \\
\hline $\begin{array}{l}\text { Control Pu-238 } \\
\text { Range } \\
\text { St. Dev. } \\
\text { \# samples }\end{array}$ & $\begin{array}{c}0.0008 \\
0-0.002 \\
0.0009 \\
5\end{array}$ & & & & \\
\hline $\begin{array}{l}\text { Control } \mathrm{Pu}-238 / 240 \\
\text { Range } \\
\text { St. Dev. } \\
\# \text { samples }\end{array}$ & $\begin{array}{c}0.0218 \\
0.002-0.05 \\
0.027 \\
5\end{array}$ & & & & \\
\hline $\begin{array}{l}\text { Control I-129 } \\
\text { Range } \\
\text { St. Dev. } \\
\text { \# samples }\end{array}$ & & & & $\begin{array}{c}-0.82 \\
1\end{array}$ & \\
\hline
\end{tabular}


Table A-2. Radionuclide Values $(\mathrm{pCi} / \mathrm{g})$ in Litter.

\begin{tabular}{|c|c|c|c|c|}
\hline ID \# & Tc-99 & $I-129$ & $\mathrm{Pu}-238$ & $\mathrm{Pu}-239$ \\
\hline Alo & & & 0.004 & 0.040 \\
\hline B10 & & & 0.004 & 0.070 \\
\hline $\mathrm{ClO}$ & & & 0.001 & 0.030 \\
\hline 1 & 0.50 & -1.69 & & \\
\hline 4 & 1.42 & -1.84 & & \\
\hline 10 & & -0.002 & & \\
\hline 12 & & -0.78 & & \\
\hline 13 & 10.89 & -0.85 & & \\
\hline 19 & 0.68 & 0.36 & & \\
\hline 22 & -0.53 & 0.21 & & \\
\hline 23 & -0.62 & 0.17 & & \\
\hline 25 & 10.06 & -1.02 & & \\
\hline 35 & 1.61 & 0.59 & & \\
\hline 40 & 0.91 & -0.27 & & \\
\hline 45 & 0.21 & 0.21 & & \\
\hline 47 & 0.43 & -0.40 & & \\
\hline 50 & 0.01 & -0.90 & & \\
\hline 51 & & 0.50 & & \\
\hline 52 & 0.71 & 0.15 & & \\
\hline $\operatorname{Max}$ & 10.89 & 0.59 & 0.004 & 0.070 \\
\hline Min & -0.62 & -1.84 & 0.001 & 0.030 \\
\hline Avg & 2.02 & -0.35 & 0.003 & 0.047 \\
\hline St. Devia & 3.81 & 0.76 & 0.002 & 0.021 \\
\hline 2St. Err & 2.11 & 0.38 & 0.002 & 0.024 \\
\hline Total number & 13 & 16 & 3 & 3 \\
\hline
\end{tabular}




\section{WHC-EP-0771}

Table A-3. Radionuclide Values ( $\mathrm{pC} i / g$ ) for Cryptogams.

\begin{tabular}{|c|c|c|c|c|}
\hline ID \# & Tc-99 & $I-129$ & $\mathrm{Pu}-238$ & $\mathrm{Pu}-239$ \\
\hline A10 & & & 0.0400 & 0.0100 \\
\hline B10 & & & 0.0700 & 0.0300 \\
\hline $\mathrm{C} 10$ & & & 0.0400 & 0.0000 \\
\hline 1 & & -2.81 & & \\
\hline 2 & 0.08 & & & \\
\hline 4 & & -1.77 & & \\
\hline 10 & & -0.09 & & \\
\hline 12 & & -0.68 & & \\
\hline 13 & & 0.91 & & \\
\hline 19 & 0.60 & 0.01 & & \\
\hline 22 & & 0.76 & & \\
\hline 23 & 1.23 & 0.43 & & \\
\hline 25 & & 0.07 & & \\
\hline 27 & & -0.11 & & \\
\hline 35 & 1.33 & 0.22 & & \\
\hline 37 & & 0.57 & & \\
\hline 39 & & -0.38 & & \\
\hline 45 & 0.48 & 1.35 & & \\
\hline 47 & & 0.28 & & \\
\hline 51 & & -0.66 & & \\
\hline 52 & 1.50 & -0.76 & & \\
\hline $\operatorname{Max}$ & 1.50 & 1.35 & 0.0700 & 0.0300 \\
\hline Min & 0.08 & -2.81 & 0.0400 & 0.0000 \\
\hline Avg & 0.87 & -0.16 & 0.0500 & 0.0133 \\
\hline St. Devia & 0.56 & 1.00 & 0.0173 & 0.0153 \\
\hline 2St. Err & 0.46 & 0.49 & 0.0200 & 0.0176 \\
\hline Total number & 6 & 17 & 3 & 3 \\
\hline
\end{tabular}


WHC-EP-0771

Table A-4. Radionuclide Values $(p C i / g)$ for Soil. (sheet 1 of 3 )

\begin{tabular}{|c|c|c|c|c|}
\hline ID \# & $\mathrm{Pu}-238$ & $\mathrm{Pu}-239 / 240$ & Tc-99 & $I-129$ \\
\hline$A O$ & -0.003 & 0.010 & & \\
\hline$A 2$ & & 0.010 & & \\
\hline$A 3$ & & 0.010 & & \\
\hline A4 & & 0.020 & & \\
\hline A5 & & 0.030 & & \\
\hline$A X$ & & 0.010 & & \\
\hline$A 6$ & & 0.010 & & \\
\hline A7 & & 0.030 & & \\
\hline$A 8$ & & 0.020 & & \\
\hline $\mathrm{A9}$ & & 0.010 & & \\
\hline A10 & & 0.010 & & \\
\hline A14 & -0.004 & 0.007 & & \\
\hline \multicolumn{5}{|l|}{ BO } \\
\hline B1 & & 0.010 & & \\
\hline \multicolumn{5}{|l|}{ B2 } \\
\hline B3 & & 0.010 & & \\
\hline \multicolumn{5}{|l|}{$B 4$} \\
\hline B5 & & 0.010 & & \\
\hline \multicolumn{5}{|l|}{ B6 } \\
\hline B7 & & 0.010 & & \\
\hline \multicolumn{5}{|l|}{ B8 } \\
\hline \multicolumn{5}{|l|}{$\mathrm{Bg}$} \\
\hline $\mathrm{B} 10$ & & 0.020 & & \\
\hline B11 & -0.004 & 0.010 & & \\
\hline \multicolumn{5}{|l|}{$\mathrm{CO}$} \\
\hline $\mathrm{C} 1$ & & 0.010 & & \\
\hline \multicolumn{5}{|l|}{$\mathrm{C} 2$} \\
\hline \multicolumn{5}{|l|}{ C3 } \\
\hline C4 & & 0.010 & & \\
\hline $\mathrm{C5}$ & & & & \\
\hline C6 & & 0.010 & & \\
\hline$C 7$ & & & & \\
\hline
\end{tabular}


WHC-EP-0771

Table A-4. Radionuclide Values $(\mathrm{pCi} / \mathrm{g})$ for Soil. (sheet 2 of 3 )

\begin{tabular}{|c|c|c|c|c|}
\hline ID \# & $\mathrm{Pu}-238$ & $\mathrm{Pu}-239 / 240$ & Tc-99 & $1-129$ \\
\hline $\mathrm{CB}$ & & 0.010 & & \\
\hline \multicolumn{5}{|l|}{ C9 } \\
\hline $\mathrm{ClO}$ & & 0.010 & & \\
\hline $\mathrm{Cll}$ & 0.0008 & 0.005 & & \\
\hline 1 & 0.0009 & 0.018 & 0.13 & -0.210 \\
\hline \multicolumn{5}{|l|}{2} \\
\hline \multicolumn{5}{|l|}{3} \\
\hline 4 & 0.0007 & 0.044 & 0.41 & -0.060 \\
\hline \multicolumn{5}{|l|}{5} \\
\hline 6 & 0.0002 & 0.016 & & \\
\hline 7 & 0.0005 & 0.031 & & \\
\hline 8 & - & & & \\
\hline \multicolumn{5}{|l|}{9} \\
\hline 10 & & & 0.23 & -0.040 \\
\hline 11 & 0.0002 & 0.015 & & \\
\hline 12 & 0.0003 & 0.022 & & \\
\hline 13 & & & 0.53 & -0.900 \\
\hline \multicolumn{5}{|l|}{14} \\
\hline 15 & 0.0009 & 0.130 & & \\
\hline \multicolumn{5}{|l|}{16} \\
\hline 17 & 0.0005 & 0.019 & & \\
\hline 18 & & & 0.85 & -0.300 \\
\hline 19 & & & & 0.800 \\
\hline 20 & 0.0006 & 0.060 & & \\
\hline \multicolumn{5}{|l|}{21} \\
\hline 22 & 0.0003 & 0.013 & 0.95 & 0.400 \\
\hline 23 & & 0.010 & & 0.090 \\
\hline 24 & & 0.011 & & \\
\hline 25 & & & 0.57 & -0.070 \\
\hline 26 & & 0.014 & & \\
\hline 27 & & & & 0.100 \\
\hline 28 & & 0.070 & & \\
\hline
\end{tabular}


Table A-4. Radionuclide Values $(\mathrm{pCi} / \mathrm{g}$ ) for Soil. (sheet 3 of 3 )

\begin{tabular}{|c|c|c|c|c|}
\hline ID \# & $\mathrm{Pu}-238$ & $\mathrm{Pu}-239 / 240$ & Tc-99 & I-129 \\
\hline \multicolumn{5}{|l|}{29} \\
\hline 30 & 0.0008 & 0.1200 & & \\
\hline 31 & 0.0010 & 0.0700 & & \\
\hline 32 & 0.0009 & 0.0500 & & \\
\hline 33 & 0.0004 & 0.0300 & & \\
\hline 34 & 0.0004 & 0.0200 & & \\
\hline 35 & 0.0010 & 0.0400 & 0.42 & -0.500 \\
\hline 36 & 0.0003 & 0.0200 & & \\
\hline 37 & 0.0006 & 0.0380 & & \\
\hline 38 & 0.0004 & 0.0200 & & \\
\hline 39 & 0.0003 & 0.0100 & 0.49 & -0.510 \\
\hline 40 & & & 9.44 & 0.390 \\
\hline 41 & 0.0004 & 0.0200 & & \\
\hline \multicolumn{5}{|l|}{42} \\
\hline 43 & 0.0005 & 0.0200 & & \\
\hline \multicolumn{5}{|l|}{44} \\
\hline 45 & 0.0001 & 0.0100 & 0.93 & -0.480 \\
\hline \multicolumn{5}{|l|}{46} \\
\hline 47 & 0.0003 & 0.0100 & & -0.430 \\
\hline \multicolumn{5}{|l|}{48} \\
\hline 49 & 0.0003 & 0.0100 & & \\
\hline 50 & & & 0.60 & -0.560 \\
\hline 51 & & & & 0.270 \\
\hline 52 & & & & -0.340 \\
\hline $\operatorname{Max}$ & 0.0010 & 0.1300 & 9.44 & 0.80 \\
\hline Min & -0.0040 & 0.0050 & 0.13 & -0.90 \\
\hline Avg & 0.0001 & 0.0238 & 1.30 & -0.13 \\
\hline St. Dev & 0.0013 & 0.0253 & 2.58 & 0.42 \\
\hline 2St. Err & 0.0005 & 0.0070 & 1.49 & 0.20 \\
\hline Total number & 29 & 53 & 12 & 18 \\
\hline
\end{tabular}


WHC-EP-0771

Table A-5. Radionuclide Values $(\mathrm{pC} \mathrm{i} / \mathrm{g}$ ) for Sagebrush.

\begin{tabular}{|c|c|c|c|c|}
\hline ID \# & $\mathrm{Pu}-238$ & $\mathrm{Pu}-239 / 240$ & Tc-99 & $I-129$ \\
\hline $\mathrm{AO}$ & 0.0004 & 0.0020 & & \\
\hline $\mathrm{A} 2$ & & 0.0100 & & \\
\hline A5 & & 0.0100 & & \\
\hline A6 & & 0.0100 & & \\
\hline Alo & & 0.0100 & & \\
\hline A14 & 0.2000 & 1.51 & & \\
\hline $\mathrm{Bl}$ & & 0.0100 & & \\
\hline B3 & & 0.0100 & & \\
\hline 85 & & 0.0100 & & \\
\hline $\mathrm{B} 10$ & & 0.0100 & & \\
\hline B11 & 0.0009 & 0.005 & & \\
\hline $\mathrm{CO}$ & 0.0002 & 0.0030 & & \\
\hline C6 & - & 0.0200 & & \\
\hline $\mathrm{ClO}$ & & 0.0100 & & \\
\hline C11 & 0.0004 & 0.0030 & & \\
\hline 1 & & & 1.73 & 0.36 \\
\hline 18 & & & 0.56 & 0.29 \\
\hline 19 & & & 0.34 & 0.01 \\
\hline 23 & & & 2.01 & 0.47 \\
\hline 39 & & & 1.61 & 0.39 \\
\hline 50 & & & 7.22 & 0.50 \\
\hline $\operatorname{Max}$ & 0.20 & 1.51 & 7.22 & 0.50 \\
\hline Min & 0.00 & 0.00 & 0.34 & 0.01 \\
\hline Avg & 0.04 & 0.11 & 2.25 & 0.34 \\
\hline St. Dev & 0.09 & 0.39 & 2.53 & 0.18 \\
\hline 2St. Err & 0.08 & 0.20 & 2.06 & 0.14 \\
\hline Total number & 5 & 15 & 6 & 6 \\
\hline
\end{tabular}


WHC-EP-0771

Table A-6. Cesium-137 and Strontium-90 Values for Small Mammals. (sheet 1 of 2)

\begin{tabular}{|c|c|c|}
\hline ID \# & Cs-137 & $5 r-90$ \\
\hline A2 & 0.02 & \\
\hline A4 & 0.10 & \\
\hline A5 & 0.01 & 0.02 \\
\hline$A X$ & 0.06 & \\
\hline A6 & 0.01 & 0.05 \\
\hline A7 & 0.27 & \\
\hline A9 & 0.02 & 0.02 \\
\hline A10 & 0.08 & \\
\hline B1 & 0.70 & \\
\hline B2 & 0.05 & 0.07 \\
\hline B3 & 0.16 & \\
\hline B4 & 0.10 & 0.14 \\
\hline B5 & 0.29 & \\
\hline B7 & 0.01 & \\
\hline $\mathrm{Bg}$ & 0.64 & 0.05 \\
\hline B10 & 0.69 & \\
\hline $\mathrm{Cl}$ & 0.28 & \\
\hline C2 & 0.01 & 0.06 \\
\hline C4 & 0.05 & \\
\hline C6 & 0.06 & \\
\hline$C 7$ & 0.09 & 0.16 \\
\hline C8 & 0.06 & \\
\hline $\mathrm{Cg}$ & 0.01 & 0.06 \\
\hline $\mathrm{ClO}$ & 0.28 & \\
\hline 1 & 0.00 & \\
\hline 2 & 0.11 & \\
\hline 3 & 0.14 & \\
\hline 11 & 0.05 & \\
\hline 12 & 0.11 & \\
\hline
\end{tabular}




\section{WHC-EP-0771}

Table A-6. Cesium-137 and Strontium-90 Values for Small Mammals. (sheet 2 of 2)

\begin{tabular}{|l|c|c|}
\hline \multicolumn{1}{|c|}{ ID \# } & Cs-137 & Sr-90 \\
\hline 13 & 0.18 & \\
\hline 42 & -0.15 & \\
\hline 43 & -0.03 & \\
\hline Max & 0.70 & 0.16 \\
\hline Min & -0.15 & 0.02 \\
\hline Avg & 0.14 & 0.07 \\
\hline St. Dev & 0.20 & 0.05 \\
\hline 2St. Err & 0.07 & 0.03 \\
\hline Total number & 32 & 9 \\
\hline
\end{tabular}


Table A-7. Strontium-90 Values for all Media. (sheet 1 of 3 )

\begin{tabular}{|c|c|c|c|c|}
\hline ID \# & Soil & Sage & Litter & Cryptogams \\
\hline$A O$ & 0.18 & 0.09 & 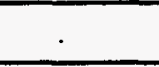 & \\
\hline A2 & 0.22 & 0.13 & 0.70 & 0.20 \\
\hline A3 & 0.17 & 1.60 & & \\
\hline$\overline{\mathrm{A} 4}$ & 0.18 & 0.78 & & \\
\hline$A 5$ & 0.57 & 0.31 & 0.80 & 0.60 \\
\hline$A X$ & 0.38 & 0.30 & & \\
\hline$A 6$ & 0.35 & 0.33 & & \\
\hline A7 & 0.40 & 0.43 & & \\
\hline$A 8$ & 0.37 & 0.33 & & \\
\hline A9 & 0.36 & 0.42 & & \\
\hline $\mathrm{AlO}$ & 0.18 & 0.61 & 0.65 & 0.35 \\
\hline A11 & 0.34 & 0.50 & & \\
\hline $\mathrm{Al2}$ & 0.41 & 0.01 & & \\
\hline $\mathrm{A} 13$ & 0.12 & 0.03 & & \\
\hline A14 & 0.19 & 0.01 & & \\
\hline $\mathrm{BO}$ & 0.23 & 0.04 & & \\
\hline $\mathrm{B1}$ & 0.19 & 0.34 & 0.16 & 0.22 \\
\hline$B 2$ & 0.17 & 0.26 & & \\
\hline B3 & 0.10 & 0.37 & & \\
\hline B4 & 0.20 & 0.22 & & \\
\hline $\mathrm{B} 5$ & 0.16 & 0.19 & & \\
\hline$B 6$ & 0.34 & 0.28 & & \\
\hline$B 7$ & 0.16 & 0.32 & 0.24 & 0.29 \\
\hline B8 & 0.30 & 0.43 & & \\
\hline $\mathrm{B9}$ & 0.04 & 5.82 & & \\
\hline B10 & 0.23 & 0.25 & 1.65 & 1.21 \\
\hline $\mathrm{B} 11$ & 0.21 & 0.12 & & \\
\hline $\mathrm{CO}$ & 0.21 & 0.12 & & \\
\hline $\mathrm{Cl}$ & 0.24 & 0.26 & 0.15 & 0.52 \\
\hline $\mathrm{C} 2$ & 0.20 & 0.87 & & \\
\hline C3 & 0.24 & 0.23 & & \\
\hline $\mathrm{C4}$ & 0.26 & 0.15 & 0.05 & 0.56 \\
\hline $\mathrm{C} 5$ & 0.25 & 0.19 & & \\
\hline $\mathrm{C6}$ & 0.10 & 0.22 & & \\
\hline
\end{tabular}


WHC-EP-0771

Table A-7. Strontium-90 Values for all Media. (sheet 2 of 3)

\begin{tabular}{|c|c|c|c|c|}
\hline ID \# & Soil & Sage & Litter & Cryptogams \\
\hline $\mathrm{C7}$ & 0.13 & 0.36 & & \\
\hline $\mathrm{CB}$ & 0.18 & 0.26 & & \\
\hline $\mathrm{Cg}$ & 0.20 & 0.25 & & \\
\hline $\mathrm{ClO}$ & 0.23 & 0.24 & 0.39 & 1.40 \\
\hline $\mathrm{C11}$ & 0.08 & 0.13 & & \\
\hline 1 & 2.21 & 2.48 & 5.72 & 4.78 \\
\hline 2 & & 2.48 & & \\
\hline 3 & & & 2.76 & \\
\hline 4 & 0.46 & 1.56 & 1.98 & 2.44 \\
\hline \multicolumn{5}{|l|}{5} \\
\hline 6 & & 2.49 & 4.35 & \\
\hline \multicolumn{5}{|l|}{7} \\
\hline 8 & & & & 1.69 \\
\hline 9 & & & 1.87 & \\
\hline 10 & 0.23 & 0.34 & & \\
\hline 11 & & 1.99 & 1.31 & \\
\hline 12 & & 1.27 & & . \\
\hline 13 & 1.08 & & 2.37 & \\
\hline \multicolumn{5}{|l|}{14} \\
\hline 15 & & 1.25 & & 1.65 \\
\hline \multicolumn{5}{|l|}{16} \\
\hline 17 & & & 0.61 & \\
\hline 18 & 0.49 & & 1.28 & \\
\hline 19 & 0.71 & 0.69 & & \\
\hline \multicolumn{5}{|l|}{20} \\
\hline 21 & & 1.14 & & 1.60 \\
\hline 22 & 0.65 & & & \\
\hline 23 & & & & 0.90 \\
\hline 24 & & & 0.58 & \\
\hline 25 & 0.42 & & 1.78 & \\
\hline 26 & & & 1.38 & 0.67 \\
\hline 27 & & 0.24 & 0.65 & \\
\hline 28 & & 4.10 & 5.25 & 0.41 \\
\hline 29 & & & & \\
\hline
\end{tabular}


WHC-EP-0771

Table A-7. Strontium-90 Values for all Media. (sheet 3 of 3 )

\begin{tabular}{|c|c|c|c|c|}
\hline ID \# & Soil & Sage & Litter & Cryptogams \\
\hline 30 & 1.1 & & & \\
\hline 31 & 0.73 & & 1.71 & \\
\hline 32 & 0.83 & 0.99 & & \\
\hline 33 & 0.83 & & & 3.02 \\
\hline 34 & 0.88 & & & 1.40 \\
\hline 35 & 0.98 & 0.72 & 4.68 & 1.41 \\
\hline 36 & 0.88 & & & \\
\hline 37 & & & 1.88 & \\
\hline 38 & 0.66 & & & 2.26 \\
\hline 39 & 0.56 & 1.52 & 1.48 & 1.59 \\
\hline 40 & & & & 1.15 \\
\hline 41 & & 0.81 & 3.38 & 0.82 \\
\hline \multicolumn{5}{|l|}{42} \\
\hline 43 & & & & 1.54 \\
\hline 44 & & & 2.66 & \\
\hline 45 & 0.53 & 1.00 & & 1.87 \\
\hline \multicolumn{5}{|l|}{46} \\
\hline 47 & 0.54 & 0.12 & & 0.84 \\
\hline 48 & & & 1.18 & \\
\hline 49 & & & & 1.10 \\
\hline 50 & 0.43 & 1.49 & & \\
\hline \multicolumn{5}{|l|}{51} \\
\hline \multicolumn{5}{|l|}{52} \\
\hline $\operatorname{Max}$ & 2.21 & 5.82 & 5.72 & 4.78 \\
\hline Min & 0.04 & 0.01 & 0.05 & 0.20 \\
\hline Avg & 0.41 & 0.75 & 1.78 & 1.30 \\
\hline St. Devia & 0.36 & 1.04 & 1.51 & 0.98 \\
\hline 2St. Err & 0.09 & 0.28 & 0.54 & 0.37 \\
\hline Total number & 59 & 57 & 31 & 28 \\
\hline
\end{tabular}


WHC-EP-0771

Table A-8. Cesium-137 Values for all Media. (sheet 1 of 3)

\begin{tabular}{|c|c|c|c|c|}
\hline ID \# & Soil & Sage & Litter & Cryptogams \\
\hline AO & 0.63 & 0.16 & & \\
\hline$A 2$ & 0.46 & 0.28 & 6.38 & 2.04 \\
\hline A3 & 0.27 & 0.84 & & \\
\hline A4 & 0.28 & 0.94 & 9.84 & 3.13 \\
\hline$A 5$ & 0.86 & 0.20 & 7.68 & 2.29 \\
\hline$A X$ & 0.52 & 0.69 & & \\
\hline A6 & 0.90 & 0.63 & 6.35 & 4.70 \\
\hline A7 & 0.95 & 0.85 & & \\
\hline A8 & 1.09 & 0.43 & & \\
\hline A9 & 1.06 & 1.33 & 10.20 & 5.40 \\
\hline A10 & 0.48 & 1.48 & 5.60 & 4.87 \\
\hline All & 0.49 & 0.27 & & \\
\hline Al2 & 1.84 & 0.12 & & \\
\hline A13 & 0.81 & 0.37 & & \\
\hline A14 & 0.77 & 0.13 & & \\
\hline BO & 0.74 & 0.11 & & \\
\hline $\mathrm{B} 1$ & 0.48 & 0.21 & 0.82 & 1.43 \\
\hline B2 & 0.54 & 0.27 & & \\
\hline B3 & 0.27 & 0.39 & 2.10 & 2.12 \\
\hline B4 & 0.24 & 0.46 & & \\
\hline$B 5$ & 0.87 & 0.35 & 3.17 & 2.83 \\
\hline B6 & 0.56 & 0.48 & 1.62 & 2.21 \\
\hline B7 & 0.71 & 1.21 & 3.09 & 1.53 \\
\hline $\mathrm{B} 8$ & 0.80 & 1.69 & & \\
\hline B9 & 0.39 & 4.99 & & \\
\hline $\mathrm{B} 10$ & 0.75 & 0.60 & 4.02 & 6.10 \\
\hline B11 & 0.71 & 0.43 & & \\
\hline $\mathrm{CO}$ & 0.62 & 0.31 & & \\
\hline $\mathrm{Cl}$ & 0.65 & 0.17 & 1.74 & 1.68 \\
\hline C2 & 0.64 & 0.56 & & \\
\hline C3 & 0.43 & 0.16 & 3.94 & 2.86 \\
\hline C4 & 0.48 & 0.41 & & \\
\hline$C 5$ & 0.41 & 0.43 & 0.47 & 4.54 \\
\hline C6 & 0.22 & 0.45 & 0.80 & 2.85 \\
\hline
\end{tabular}


Table A-8. Cesium-137 Values for all Media. (sheet 2 of 3)

\begin{tabular}{|c|c|c|c|c|}
\hline ID \# & Soil & Sage & Litter & Cryptogams \\
\hline C7 & 0.56 & 0.70 & & \\
\hline$C 8$ & 0.40 & 0.32 & 1.73 & 4.36 \\
\hline C9 & 0.40 & 0.37 & & \\
\hline $\mathrm{ClO}$ & 0.59 & 0.79 & 1.73 & 2.79 \\
\hline $\mathrm{C} 11$ & 0.17 & 0.18 & & \\
\hline 1 & 55.00 & 33.10 & 36.40 & 68.20 \\
\hline 2 & 1.94 & 0.97 & 62.90 & 49.40 \\
\hline 3 & 1.99 & 0.80 & 70.80 & 18.50 \\
\hline 4 & & & & 900.00 \\
\hline 4 & 10.70 & 1.62 & 20.90 & 36.00 \\
\hline 5 & 8.21 & 1.51 & 96.30 & 12.10 \\
\hline 6 & 5.15 & 1.24 & 23.90 & 27.70 \\
\hline 7 & 4.02 & 0.64 & 15.40 & 7.70 \\
\hline 8 & 3.05 & 0.43 & 27.00 & 9.90 \\
\hline 9 & 2.53 & 0.46 & 18.40 & 5.40 \\
\hline 10 & & 0.31 & 6.38 & 3.44 \\
\hline 11 & 2.12 & 1.07 & 8.32 & 3.10 \\
\hline 12 & 1.80 & 0.73 & 28.20 & 5.84 \\
\hline 13 & 0.60 & 0.04 & 4.69 & 7.71 \\
\hline 14 & 2.01 & 1.17 & 0.97 & \\
\hline 15 & 1.95 & 0.48 & 10.10 & 7.45 \\
\hline 16 & 2.38 & 0.56 & 4.00 & 2.78 \\
\hline 17 & 1.93 & 0.28 & 2.30 & 3.14 \\
\hline 18 & 1.79 & 0.34 & 2.71 & \\
\hline 19 & & 0.66 & 17.40 & 4.38 \\
\hline 20 & 2.10 & 0.51 & 22.00 & 17.70 \\
\hline 21 & 1.25 & 0.43 & 10.10 & 5.40 \\
\hline 22 & 0.55 & 0.34 & 2.71 & 4.20 \\
\hline 23 & 0.76 & 0.34 & 8.14 & \\
\hline 24 & 1.72 & 0.39 & 1.45 & 1.73 \\
\hline 25 & 0.57 & 0.59 & 14.80 & 3.76 \\
\hline 26 & 0.78 & 0.32 & 2.18 & 1.68 \\
\hline 27 & 0.42 & 0.43 & 6.32 & 0.82 \\
\hline 28 & 0.37 & 0.29 & 1.02 & 0.88 \\
\hline
\end{tabular}


Table A-8. Cesium-137 Values for all Media. (sheet 3 of 3 )

\begin{tabular}{|c|c|c|c|c|}
\hline ID \# & Soil & Sage & Litter & Cryptogams \\
\hline 29 & 13.40 & 0.26 & 22.70 & 9.77 \\
\hline 30 & & 0.47 & & \\
\hline 31 & 2.45 & 0.94 & 6.53 & 4.68 \\
\hline 32 & 3.44 & 0.63 & 28.10 & 4.99 \\
\hline 33 & 4.07 & 0.85 & 24.20 & 13.80 \\
\hline 34 & 2.10 & 0.69 & 20.10 & 8.63 \\
\hline 35 & 2.88 & 0.42 & 22.20 & 7.43 \\
\hline 36 & 2.44 & 0.41 & 11.30 & 10.80 \\
\hline 37 & 2.60 & 0.89 & 6.41 & 5.61 \\
\hline 38 & 2.26 & 0.66 & 16.20 & 11.40 \\
\hline 39 & 1.13 & 1.05 & 7.58 & 8.18 \\
\hline 40 & 4.59 & 0.36 & 8.78 & 5.33 \\
\hline 41 & 0.84 & 0.46 & 8.87 & 3.18 \\
\hline 42 & 1.29 & 1.08 & 28.20 & 15.80 \\
\hline 43 & 1.11 & 0.64 & 23.40 & 6.98 \\
\hline 44 & 1.47 & 1.40 & 14.60 & 6.50 \\
\hline 45 & 2.92 & 1.13 & 9.61 & 12.40 \\
\hline 46 & 1.48 & 1.39 & 4.74 & 13.90 \\
\hline 47 & 0.95 & 2.61 & 25.40 & 4.78 \\
\hline 48 & 1.71 & 2.10 & 12.20 & 6.69 \\
\hline 49 & 1.66 & & 28.10 & 8.48 \\
\hline 50 & 3.10 & 1.40 & 15.10 & 8.56 \\
\hline \multicolumn{5}{|l|}{51} \\
\hline \multicolumn{5}{|l|}{52} \\
\hline Max & 55.00 & 33.10 & 96.30 & 900.00 \\
\hline Min & 0.17 & 0.04 & 0.47 & 0.82 \\
\hline Avg & 2.30 & 1.07 & 14.05 & 22.22 \\
\hline St. Devia & 6.11 & 3.52 & 16.67 & 111.12 \\
\hline 2St. Err & 1.32 & 0.75 & 4.07 & 27.57 \\
\hline Total number & 86 & 88 & 67 & 65 \\
\hline
\end{tabular}




\section{DISTRIBUTION}

\section{Number of copies}

OFFSITE

$3 \quad$ U.S. Environmental Protection Agency

Olympia, Washington

D. R. Einan

P. S. Innis

D. R. Sherwood

3 Washington State Department of Ecology Mail Stop PV-11

O1ympia, Washington 98504-8711

C. Cline

L. Goldstein

D. Teal

1 Washington State Department of Wildlife Lower River Road

Benton City, Washington 99320

L. Fitzner

1 Washington State Department of Wildlife 2802 Fruitvale Blvd.

Yakima, Washington 98902

$5 \quad$ National Heritage Data System

Washington Department of Natural Resources and Department of Wildl ife - Nongame Program c/o Mail Stop EX-12 Olympia, Washington 98504

J. Gammon

M. Sheehan (3)

R. Shuler 


\section{OFFSITE}

\section{DISTRIBUTION (cont)}

2

Nature Conservancy

Washington Field Office

217 Pine St. Suite 1100

Seattle, Washington 98101

C. Soper (2)

ONSITE

14

U.S. Department of EnergyRichland Field office

J. Erickson

E. D. Goller

A5-19

J. D. Goodenough

A5-19

T.W. Ferns

Pubiic Reading Room

A5-19

Al-65

6

Bechtel Hanford Company

K. R. Fecht

H4-80

R. D. Fox

$\mathrm{H} 6-07$

K. A. Gano

$\mathrm{X} 0-21$

S. J. Hope

$\mathrm{H} 4-79$

$T$. D. Lefrancois

H4-79

R. Ovink

H4-79

11

Pacific Northwest Laboratory

C. A. Brandt

K6-09

L. L. Cadwell

K6-63

S. A. Carver

P8-55

C. E. Cushing

P7-59

D. D. Dauble

K6-09

S. L. Friant

$\mathrm{K} 6-13$

G. W. Gee

$\mathrm{K} 6-77$

K. L. Petersen

K6-60

D. E. Robertson

L. Rogers

Technical Library.

P8-01

P7-54

P8-55

\section{Westinghouse Hanford Company}

M. R. Adams

H4-55

S. W. Clark

J. J. Dorian

H4-55

H6-20

R. H. Engelmann

$\mathrm{H} 4-57$

C. J. Geier

R2-36

E. W. Gerber

R3-86

E. M. Greager

L6-60

S. J. Guzek

L6-58 
WHC-EP-0771

\section{DISTRIBUTION (cont)}

C. E. Heiden

H4-55

G. Henckel

R. P. Hencke 1

H4-55

A. R. Johnson

$\mathrm{H} 4-55$

W. L. Johnson

$\mathrm{T} 1-30$

C. J. Kemp

A. D. Krug

D. S. Landeen (5)

J. G. Lucas

$\mathrm{H} 4-14$

H4-14

H4-55

H4-14

R. M. Mitchell

H4-55

N. M. Naiknimbalkar

H4-55

R. C. Roos

M. R. Sackschewsky

(5)

$\mathrm{H} 4-55$

H4-55

H4-14

J.W. Schmidt

H6-20

J. C. Sonnichsen

H4-14

M. T. Stankovich

R. S. Weeks

J.A. Stegen

H4 -55

$\mathrm{H} 4-57$

H6-04

S. G. Weiss

$\mathrm{H} 4-55$

Central Files

L8-04

Information Release

Administration

H4-17

OSTI (2)

L8-04 
WHC-EP-0771

This page intentionally left blank.

Dist-4 